\title{
The Many Roles of BAF (mSWI/SNF) and PBAF Complexes in Cancer
}

\author{
Courtney Hodges, Jacob G. Kirkland, and Gerald R. Crabtree \\ Departments of Pathology, Developmental Biology, and Genetics, Howard Hughes Medical Institute, Stanford \\ University School of Medicine, Stanford, California 94305 \\ Correspondence: crabtree@stanford.edu
}

During the last decade, a host of epigenetic mechanisms were found to contribute to cancer and other human diseases. Several genomic studies have revealed that $\sim 20 \%$ of malignancies have alterations of the subunits of polymorphic BRG-/BRM-associated factor (BAF) and Polybromo-associated BAF (PBAF) complexes, making them among the most frequently mutated complexes in cancer. Recurrent mutations arise in genes encoding several BAF/ PBAF subunits, including ARID1A, ARID2, PBRM1, SMARCA4, and SMARCB1. These subunits share some degree of conservation with subunits from related adenosine triphosphate (ATP)-dependent chromatin remodeling complexes in model organisms, in which a large body of work provides insight into their roles in cancer. Here, we review the roles of BAF- and PBAF-like complexes in these organisms, and relate these findings to recent discoveries in cancer epigenomics. We review several roles of BAF and PBAF complexes in cancer, including transcriptional regulation, DNA repair, and regulation of chromatin architecture and topology. More recent results highlight the need for new techniques to study these complexes.

\section{EPIGENOMICS IN CANCER}

Buter roadi roadly defined, epigenetic factors contribute to the expression state of the genome by regulating heritable changes in gene expression independently of the DNA sequence. Chromatin-based epigenetic regulation occurs through a wide variety of mechanisms, including physical compaction and exclusion, recruitment of transcription machinery, or covalent modification of DNA and histones. Such features constitute the heritable physicochemical state of the genetic material, and are jointly referred to as the epigenetic landscape. The combinatorial regulation of these features represents the full spectrum of achievable cell-type diversity for the organism. Because epigenetic regulation contributes to cell-type functional specialization, it is essential for multicellular life.

An important component of the epigenetic state is the regulation provided by adenosine triphosphate (ATP)-dependent chromatin remodelers, which use ATP to physically remodel histones and other factors on chromatin. As we review below, genomic studies of primary tumors and cancer cell lines have revealed that ATP-dependent chromatin remodelers are among the most frequently disrupted genes in cancer. Because several important components of ATP-dependent chromatin remodelers

Editors: Scott A. Armstrong, Steven Henikoff, and Christopher R. Vakoc

Additional Perspectives on Chromatin Deregulation in Cancer available at www.perspectivesinmedicine.org

Copyright (C) 2016 Cold Spring Harbor Laboratory Press; all rights reserved; doi: 10.1101/cshperspect.a026930

Cite this article as Cold Spring Harb Perspect Med 2016;6:a026930 
C. Hodges et al.

are conserved between yeast, flies, and humans (Fig. 1), the basic research on chromatin remodeling performed in model organisms is taking on new relevance for disease biology. In many cases, fundamental observations from yeast and flies directly support our understanding of the role of chromatin remodelers in cancer; in other cases, the differences between these organisms and humans highlight important gaps in our knowledge of disease mechanisms.

In this review, we focus on the family of BRG-/BRM-associated factor ([BAF] or mSWI/ SNF) and Polybromo-associated BAF (PBAF) complexes, whose subunits have been identified as major tumor suppressors in several malignancies (Davoli et al. 2013; Kadoch et al. 2013; Shain and Pollack 2013). Here, we relate the fundamental biology revealed by genetics, structural biology, and microscopy to the fast-moving field of cancer epigenomics. As we discuss below, the mechanisms revealed by fundamental studies inform our understanding of how epigenetic dysfunction contributes to cancer.

\section{SWI/SNF AND RSC IN Saccharomyces cerevisiae}

\section{The SWI/SNF Complex}

ATP-dependent chromatin remodelers were independently discovered in yeast, by screening for mutations that disrupt the ability of yeast to switch mating type (Stern et al. 1984) or activate sucrose fermentation pathways (Carlson et al. 1981; Neigeborn and Carlson 1984, 1987), both in response to extrinsic cues. Later work showed that many of these genes act in concert through a common complex that regulated transcription, termed SWI/SNF to honor both discoveries (Peterson and Herskowitz 1992; Winston and Carlson 1992; Cairns et al. 1994; Peterson et al. 1994). The observation that histone mutants were able to reverse the phenotypic defects associated with SWI/SNF mutation (Sternberg et al. 1987; Kruger et al. 1995) indicated that regulation of chromatin structure was the central function of the SWI/SNF complex. In vitro, ATP-dependent remodeling activity induces changes of position, phasing, stability, or histone content of nucleosomes, and is well described in other reviews (Becker and Horz 2002; Narlikar et al. 2013). However, as we discuss below, SWI/SNF-like complexes have rich and biologically diverse regulatory roles in vivo that arise through mechanisms that are not entirely clear.

In yeast, SWI/SNF is a $\sim 1.15-\mathrm{MDa}$ protein complex (Smith et al. 2003) composed of Swi1, Snf2, Swi3, Snf5, Snf6, along with Swpand actin-related proteins (ARPs) (Fig. 1). Most subunits of the complex, including the ATPase Snf2, are present as single copies in the complex, whereas several others integrate in multiple copies (two copies of Swi3, Swp82, Snf6, and Snf11, and three copies of Swp29) (Smith et al. 2003). Many of these subunits are required for the complex's biological activity and, in some cases, its biochemical stability (Estruch and Carlson 1990; Richmond and Peterson 1996). The complex's direct interaction with nucleosomal DNA is mediated by the catalytic subunit Snf2, whereas other subunits, such as Snf5, do not interact with nucleosomal DNA but instead contact the histone octamer (Dechassa et al. 2008).

Cells with SWI/SNF subunit mutations have disrupted chromatin structures, and fail to express many genes, leading to diverse phenotypic defects. As a result, several aspects of the complex's biological activity are illustrated by genetic deletion of its subunits.

Failure to activate gene expression affects several downstream processes. As an example, cells lacking the central ATPase Snf2 are viable but have impaired mating-type switching because of the inability to express the $\mathrm{HO}$ endonuclease needed for the process. Proper expression of HO depends not only on Snf2, but also Snf1 and Swi3 (Stern et al. 1984). In addition to the effects on sucrose metabolism, snf $2 \Delta$ cells also have impaired sporulation. However, SWI/SNF activity is not uniformly activating. Although Snf2 plays a role in activation of many genes, it also is required for silencing of genes at rDNA and telomeric loci, either by direct or indirect means (Dror and Winston 2004; Manning and Peterson 2014).

SWI/SNF subunits also have important functions in maintaining proper chromatin- 
A

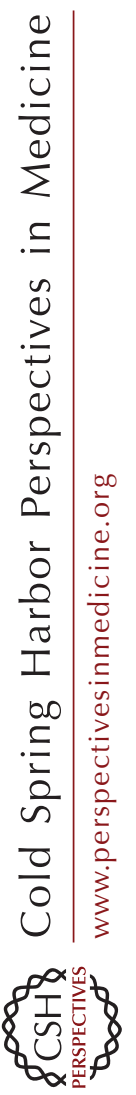

B

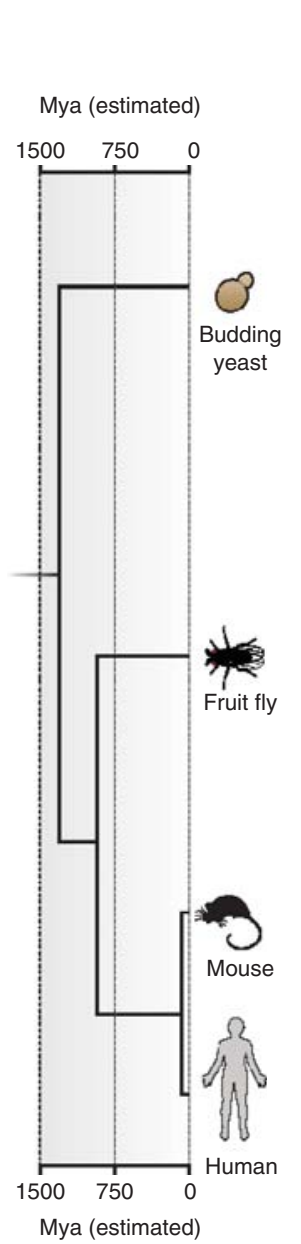

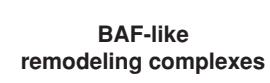

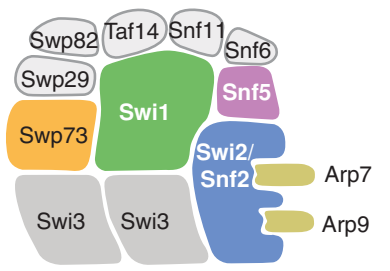

SWI/SNF complex Saccharomyces cerevisiae
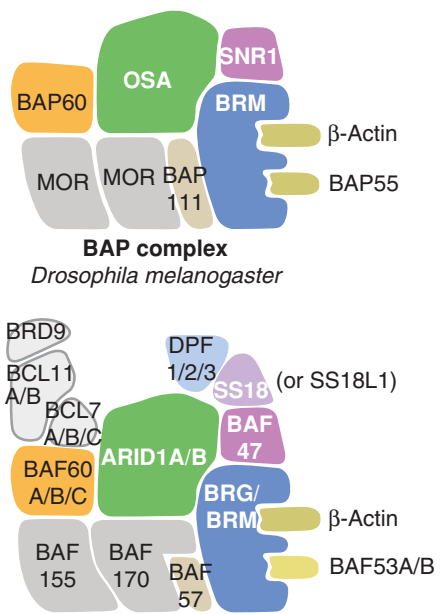

BAF complexes Homo sapiens, Mus musculus
PBAF-like remodeling complexes

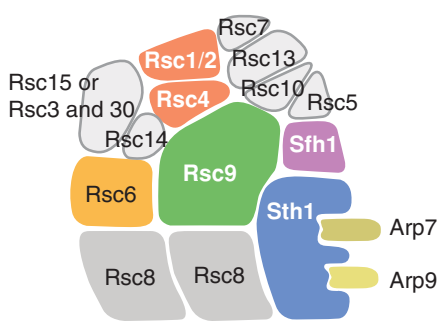

RSC complex

Saccharomyces cerevisiae

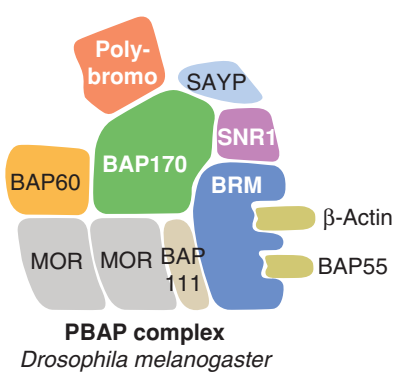

Drosophila melanogaster

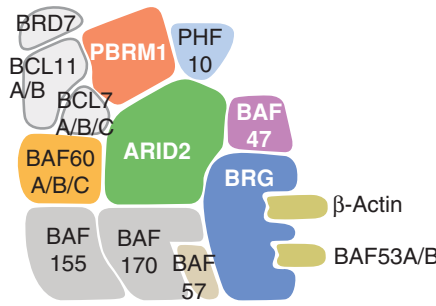

PBAF complexes

Homo sapiens, Mus musculus

\begin{tabular}{l|l|l|l}
\hline HUGO symbol & Alternative names & HUGO symbol & Alternative names \\
\hline ACTL6A/B & BAF53A/B & SMARCA2 & BRM \\
ARID1A/B & BAF250A/B & SMARCA4 & BRG \\
ARID2 & BAF200 & SMARCB1 & BAF47, SNF5, IN11 \\
BCL7A/B/C & - & SMARCC1/2 & BAF155/BAF170 \\
BCL11A/B & - & SMARCD1/2/3 & BAF60A/B/C \\
BRD7/9 & - & SMARCE1 & BAF57 \\
DPF1/2/3 & BAF45B/D/C & SS18 & - \\
PBRM1 & BAF180, Polybromo & SS18L1 & CREST \\
PHF10 & BAF45A & &
\end{tabular}

Figure 1. Homology between BAF and PBAF-like remodelers throughout evolution. (A) BAF and PBAF complexes in mammals share several features with Brahma-associated proteins (BAPs) and Polybromo-associated BAP (PBAP) complexes (Drosophila melanogaster), and SWI/SNF and RSC complexes (Saccharomyces cerevisiae), respectively. The similarities and differences between these complexes throughout evolution provide insight into their biological regulation and their roles in cancer. BAF/PBAF subunits labeled in a boldface white font have important roles in malignancy. Time since species divergence was estimated using TimeTree (Hedges et al. 2006), and plotted as a function of time, millions of years ago (Mya). (B) Summary of BAF and PBAF subunits and alternative names used in the text. In some cases, abbreviated names rather than the official human genome organization (HUGO) symbols are used in the text because of space constraints. 
C. Hodges et al.

modification domains. In a reporter strain that lacks a native transfer RNA (tRNA) insulator element, nucleosomes occupy a region from which they are normally depleted, leading to loss of insulator function (Oki et al. 2004). In this system, artificial recruitment of Snf5 or Snf6 restores the nucleosome-depleted region over which heterochromatin marks cannot spread, thereby rescuing barrier function.

SWI/SNF mutations also cause increased sensitivity to DNA-damaging agents, including hydroxyurea, cisplatin, methyl methanesulfonate, and ultraviolet (UV) light (Birrell et al. 2001; Chai et al. 2005; Xia et al. 2007). These defects may arise because SWI/SNF subunits have roles in nucleotide excision repair (Gong et al. 2006) and DNA double-strand break (DSB) repair through the homologous recombination (HR) pathway (Chai et al. 2005). SWI/ SNF defective cells also show increased sensitivity to the topoisomerase II inhibitor daunorubicin (Xia et al. 2007).

Because transcription, DNA repair, and chromatin modification domains are each influenced by the availability of accessible DNA, disruption of the nucleosome mobilization activity of SWI/SNF has distinct and pleiotropic effects.

\section{The RSC Complex}

In budding yeast, STH1 codes for the ATPase subunit of the RSC complex, which also has the capacity to remodel the structure of chromatin. In addition to Sth1, whose ATPase domain is functionally interchangeable with Snf2 (Laurent et al. 1993), the RSC complex also has Rsc4, Rsc6, Rsc8, Rsc9, Sfh1, and several other dedicated subunits (Fig. 1). In budding yeast, there are two distinct RSC complexes, containing either of the two paralogs Rsc1 or Rsc2 that arose from gene duplication. Both subunits along with Rsc4 contain bromodomains, which interact with acetylated lysines. RSC complexes are $\sim 10$-fold more abundant that SWI/SNF (Cairns et al. 1996, 1999), which may explain why RSC complexes are essential but SWI/SNF is not. Electron microscopic (EM) reconstructions of the yeast RSC complex show a lobed $\sim 1.3$-MDa structure of similar scale to the SWI/SNF complex (Asturias et al. 2002; Leschziner et al. 2007; Chaban et al. 2008).

RSC remodels nucleosomes throughout the genome, regulating the positions and densities of histones near the promoters of genes transcribed by RNA polymerase II (Pol II), as well as genes transcribed by Pol III (Parnell et al. 2008; Hartley and Madhani 2009), and its activity affects the transcription state of both classes of genes.

Rsc2 is required for insulator boundary function at the HMR locus, and its mutation leads to a loss of the nucleosome-depleted region encompassed by the insulator (Dhillon et al. 2009). Additionally, loss of Rsc2 impairs $\mathrm{HR}$ and nonhomologous end joining (NHEJ), the two DSB-repair pathways, along with repair of DNA damaged by UV light (Chai et al. 2005; Shim et al. 2005; Srivas et al. 2013). Rsc2 is present at kinetochores and is required for proper sister chromosome cohesion and chromosome segregation (Hsu et al. 2003; Baetz et al. 2004), as well as maintenance of telomeres (Askree et al. 2004).

\section{Brahma-Associated Protein (BAP) AND Polybromo-Associated BAP (PBAP) IN Drosophila melanogaster}

\section{The BAP Complex}

Complexes similar to yeast SWI/SNF were discovered in Drosophila based on their ability to oppose Polycomb repressive activity (Kennison and Tamkun 1988; Tamkun et al. 1992). The central ATPase of this complex is the gene product of brahma $(\mathrm{brm})$, giving rise to the name BAP complex. The BAP complex is defined as containing OSA and lacking BAP170, SAYP, and POLYBROMO (Fig. 1) (Mohrmann et al. 2004; Bouazoune and Brehm 2006; Chalkley et al. 2008).

In flies, the activating Trithorax group genes generally oppose the repressive activity of Polycomb group genes. Misregulation of developmental genes results in aberrant morphologies and ectopic locations of body parts. Proteins encoded by brahma, osa, and moira (mor) are 
members of the Trithorax group, a set of factors that oppose the repressive activity of Polycombgroup proteins (Kennison and Tamkun 1988; Tamkun et al. 1992; Papoulas et al. 1998; Collins et al. 1999; Crosby et al. 1999; Kal et al. 2000; Simon and Tamkun 2002; Kingston and Tamkun 2014).

Although Polycomb genes are conserved in animals, plants, and some fungi (Shaver et al. 2010), unicellular model yeasts lack Polycomb, suggesting that multicellular organisms have greater needs for repressive factors (as well as their regulators) for lineage-specific functions during development. As discussed below, failure to oppose Polycomb repressive activity in mammals plays an important role in malignancy. Nevertheless, despite this important regulatory role (likely present in the last common eukaryotic ancestor), the precise mechanisms of Polycomb opposition remain murky.

\section{The PBAP Complex}

Drosophila have a second BRM-containing complex, named PBAP. The subunit compositions of the BAP and PBAP complexes bear similarities to the functional specialization between SWI/SNF and RSC in yeast. PBAP complexes lack OSA and instead contain BAP170, SAYP, and POLYBROMO (Mohrmann et al. 2004; Bouazoune and Brehm 2006; Chalkley et al. 2008). Interestingly, BAP and PBAP subunits both genetically oppose Polycomb-mediated silencing, without regard to whether they are common to BAP and PBAP, or exclusive to one of the complexes (Kennison and Tamkun 1988; Tamkun et al. 1992; Papoulas et al. 1998; Collins et al. 1999; Crosby et al. 1999; Kal et al. 2000; Simon and Tamkun 2002). On the other hand, the complexes can also have distinct or even opposing functional roles. For example, PBAP but not BAP is required for germinal stem-cell maintenance (He et al. 2014). Moreover, BAP and PBAP have opposing roles in Egfr expression in wing development; although BAP positively regulates Egfr expression (Molnar et al. 2006; Terriente-Felix and de Celis 2009), PBAP instead negatively regulates Egfr (Rendina et al. 2010). Together, these observations suggest that mutations in different subunits or complexes may result in distinct or even opposing changes to the genomic landscape, a fact that complicates straightforward predictions of their effects.

One clue regarding the distinct functions of $\mathrm{BAP}$ and PBAP complexes comes from microscopic examination of polytene chromosomes. Polytene chromosomes arise from successive rounds of replication without cell division, resulting in many copies of aligned condensed sister chromatids (Balbiani 1881). Visualization of chromatin domains using immunofluorescence shows that BAP and PBAP complexes have both overlapping and mutually exclusive domains. Polycomb domains are largely not found at both the overlapping and mutually exclusive BAP/PBAP domains (Armstrong et al. 2002; Mohrmann et al. 2004; Moshkin et al. 2007). This pattern suggests that BAP and PBAP work both cooperatively and independently at distinct sites to oppose Polycomb silencing.

\section{BAF AND PBAF IN MAMMALS}

\section{BAF Complexes}

In mammals, highly polymorphic BAF complexes (Wang et al. 1996a,b) are composed of a single central ATPase, either BRG (SMARCA4) or BRM (SMARCA2), and several BRG-/BRMassociated factors (BAF subunits) (Khavari et al. 1993). In addition to the subunits homologous to those in Drosophila or yeast, several other subunits appear to be dedicated to vertebrate or mammalian complexes, including SS18/ SS18L1, BCL7A/B/C, BCL11/A/B, and BRD9 (see Fig. 1). Scanning force microscopy of BAF complexes isolated from HeLa cells show objects with similar appearances and dimensions as yeast SWI/SNF or RSC (Schnitzler et al. 2001); however, BAF subunits are frequently inactivated in long-term cell lines, and so caution is warranted when inferring the complex's characteristics based on immortalized cancer lines.

ChIP-seq studies in many cell types show that BAF complexes bind 20,000-40,000 sites genome-wide, with broad binding sites sometimes spanning $2-5 \mathrm{kbp}$, suggesting that more 
C. Hodges et al.

than one complex may operate at a given site (Ho et al. 2009a; Euskirchen et al. 2011). BAF complexes have many roles in development (Ho and Crabtree 2010); the presence of BAF complexes on chromatin correlates with enhancers (Rada-Iglesias et al. 2011), and its activity regulates a variety of important biological processes ranging from self-renewal and pluripotency in embryonic stem cells (Ho et al. 2009b), to cardiac development (Lickert et al. 2004), and neural differentiation (Yoo et al. 2009). BAF activity and transcription factor (TF) binding appear to be coupled idiosyncratically, as examples can be found in which TF binding requires BAF activity (Ho et al. 2011; Bao et al. 2015) or, alternatively, in which recruitment of BAF requires existing TF binding (Liu et al. 2001). Some of the complexes' subunits are tissue-specific; for example, BAF53B (ACTL6B), BAF45B (DPF1), and SS18L1 (CREST, a $\mathrm{Ca}^{2+}$-responsive regulator), are found only in BAF complexes of mature, postmitotic neurons (Olave et al. 2002; Aizawa et al. 2004; Lessard et al. 2007; Staahl et al. 2013). BAF subunit composition is subject to tight regulation, as miRNA-based repression of BAF53A occurs either before or coincident with the last mitotic division of neurons (Yoo et al. 2009), and failure to express neural-specific subunits like BAF53B leads to defects in synaptogenesis and dendritic outgrowth (Lessard et al. 2007; Vogel-Ciernia et al. 2013). BAF subunit composition also contributes substantially to cell reprogramming (Singhal et al. 2010; Yoo et al. 2011), an instructive effect seemingly incompatible with simple mechanisms of nucleosome mobilization.

Before the modern tumor-sequencing era, the frequent absence of core BAF subunits in immortalized cell lines prompted early speculation that BAF subunits were tumor suppressors (Dunaief et al. 1994). Screening for BRG mutations revealed widespread defects in a number of different cancer cell lines, and ectopic expression of $B R G$ in these lines often results in altered morphology (Wong et al. 2000). Moreover, many cell lines down-regulate both BRG and BRM ATPases (Reisman et al. 2002). In cultured cells, BAF complexes missing the core ATPase fail to bind the tumor suppressor RB1 and sup- press E2F1 (Dunaief et al. 1994; Trouche et al. 1997), although it remains uncertain whether this feature reflects its central role in primary tumors. Moreover, as described below, several specific malignancies are driven entirely by BAF subunit dysfunction. Abundant evidence now shows that BAF complexes act as major tumor suppressors.

\section{PBAF Complexes}

PBAF complexes were first discovered by Tjian and colleagues in a search for factors that activated ligand-mediated transcription on nucleosomal templates (Lemon et al. 2001). PBAF complexes contain PBRM1 and ARID2 but lack ARID1A/B. PBAF complexes also contain BRD7 in place of BRD9 (Kaeser et al. 2008), BAF45A (PHF10) instead of BAF45B/C/D (DPF1/3/2), and lack SS18 (see Fig. 1) (Middeljans et al. 2012). EM reconstruction of PBAF complexes from HeLa cells show heterogeneous $>1-\mathrm{MDa}$ structures with similarities to RSC from yeast (Leschziner et al. 2005); however, because BAF and PBAF complexes are combinatorially assembled, the origin of the observed heterogeneity of these structures remains uncertain. Several subunits share some homology with subunits of the yeast RSC complex, and like RSC, PBAF complexes show significant occupancy at the kinetochores of mitotic chromosomes (Xue et al. 2000), suggesting an important conserved role in cell division.

PBAF subunits regulate cell differentiation and may be an important regulator of cell-type identity (Bajpai et al. 2010; Xu et al. 2012). Additionally, a large body of evidence shows that PBAF complexes have important roles in the maintenance of genomic integrity during mitosis, described in more detail below (see section on Nontranscriptional Roles of BAF/PBAF Complexes in Cancer).

\section{BAF AND PBAF SUBUNITS ARE FREQUENTLY DISRUPTED IN CANCER}

In mammals, 28 genes have been discovered to date with close sequence homology with the yeast Snf2 ATPase (Fig. 2A). Despite sharing 
A

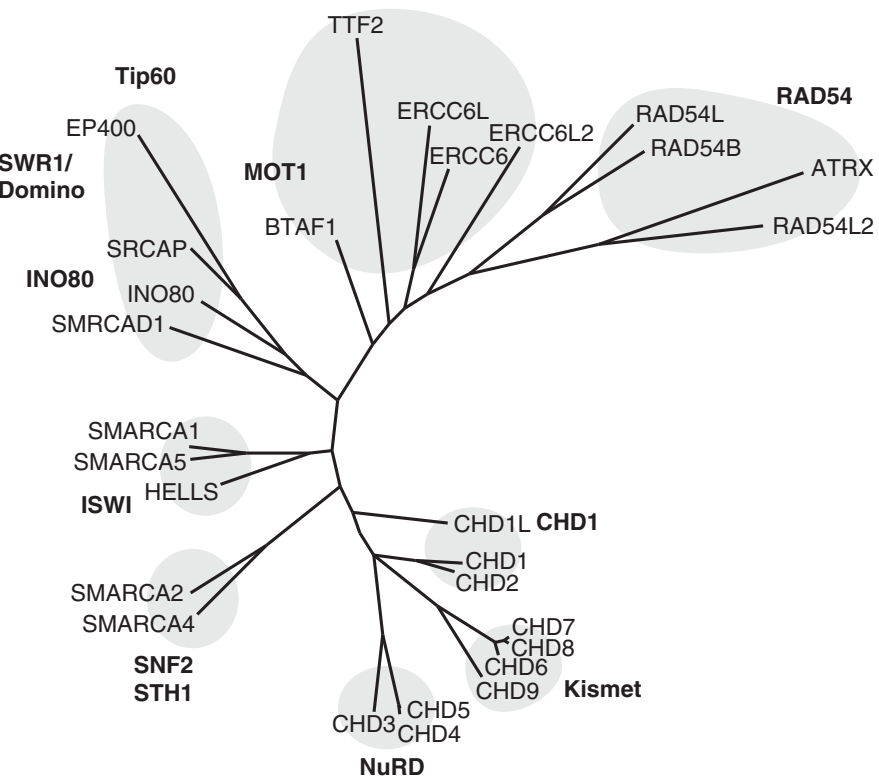

B

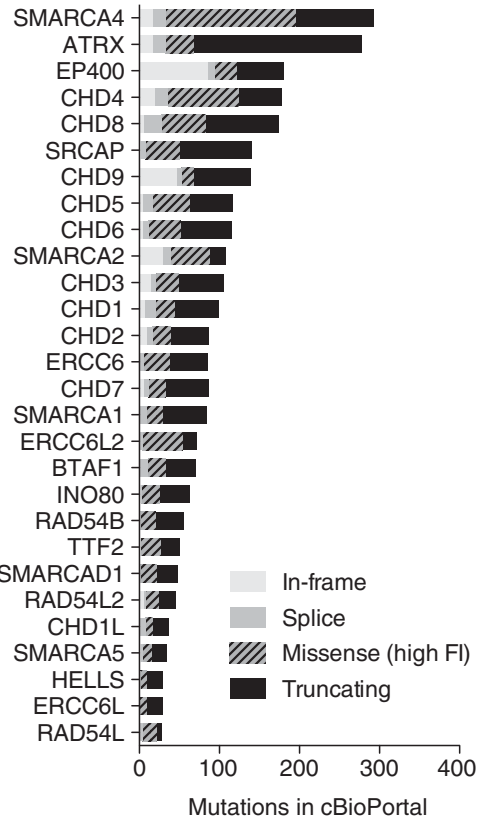

C BAF/PBAF subunits

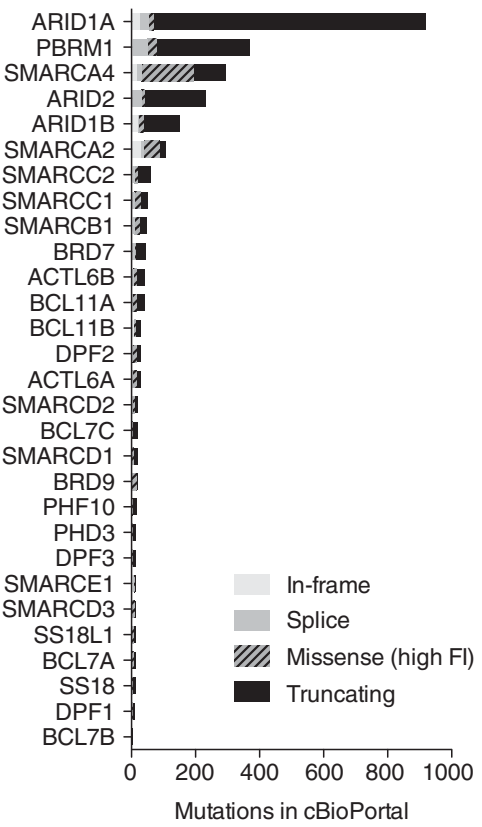

Figure 2. The family of human Snf2-like ATPases and their differing roles in cancer. (A) Human Snf2-like ATPases cluster into groups based on degree of sequence similarity. The chromatin remodelers from model organisms are shown near these groups in bold. Radial dendrogram constructed using TreeDyn (Chevenet et al. 2006). (B) Human Snf2-like ATPases are mutated at different frequencies across all cancer types. The total number of mutations appearing in cBioPortal (including public datasets from The Cancer Genome Atlas (TCGA), Cancer Cell Line Encyclopedia (CCLE), and others cited in the text) is summed for each gene and presented by the type of mutation. Missense mutations predicted to have neutral, low, or medium functional impact are not shown because of the unknown nature of their effects and increased likelihood to be background mutations. $(C)$ The number of mutations of each BAF/PBAF subunit is presented as in B. ARID1A and PBRM1 frequently undergo truncating mutation, but $B R G$ (SMARCA4) frequently has missense mutations with high functional impact. 
C. Hodges et al.

highly conserved Snf2-like ATPase domains, these ATPases play distinct biological roles and are nearly all functionally nonredundant between the different remodeling families, as reviewed elsewhere (Clapier and Cairns 2009). Based on their distinct biological activities, disruption of each of these remodelers is under a different selection pressure in cancer, resulting in a wide range of mutation frequencies (Fig. $2 B)$. Across all cancer types, $\sim 20 \%$ of human malignancies have defects in BAF-related complexes (Kadoch et al. 2013; Shain and Pollack 2013) making them among the most frequently mutated chromatin regulatory complexes in malignancy.

In addition to their ATPases BRG and BRM (Khavari et al. 1993), BAF and PBAF complexes contain a number of noncatalytic subunits that contribute to targeting of the complex to cognate loci, or have other unknown functions. BAF and PBAF complexes collectively contain eight bromodomains (six on PBRM1, one on either BRG or BRM, and one on BRD7 or BRD9), a region homologous with chromodomains (BAF155/170), two PHD finger proteins (BAF45 subunits), a large number of zinc finger and other DNA-binding domains that bind distinct architectural features such as AT-rich sequences or HMG recognition features (Wang et al. 1996a,b, 1998; Lessard et al. 2007). Some of these subunits are among the most frequently mutated genes in cancer, and highly subunit-specific mutation patterns contribute to different cancer types (Figs. 2C and 3). Below, we summarize the role of these subunits in the complex, and discuss their contribution to malignancy.

\section{BRG (SMARCA4) Is Mutated in Many Different Malignancies}

As defined by the overall number of truncating and high-functional-impact mutations, $B R G$ is the most frequently mutated Snf2-like chromatin remodeling ATPase in cancer (Fig. 2C). Unlike many other tumor suppressors, hypermethylation and silencing of $B R G$ is reported to be relatively uncommon (Medina et al. 2004; Ramos et al. 2014). However, heterozygous and biallelic inactivation of $B R G$ occurs in tumors of the breast (The Cancer Genome Atlas 2012b), lung (The Cancer Genome Atlas 2014c), stomach (The Cancer Genome Atlas 2014a), bladder (The Cancer Genome Atlas 2014b), colon (The Cancer Genome Atlas 2012a), and in several other tumor types and cell lines (Wong et al. 2000). Disruption of $B R G$ is especially common in small cell ovarian cancer (90\%-100\%) (Jelinic et al. 2014; Ramos et al. 2014), cancers of the skin (up to 27\%) (Hodis et al. 2012; Li et al. 2015; Shain et al. 2015; The Cancer Genome Atlas 2015), diffuse large B-cell lymphoma (10\%), and non-smallcell lung cancers $(\sim 11 \%)$ (Imielinski et al. 2012; Rizvi et al. 2015), in which it has been reported as the fifth most frequently mutated gene (Medina et al. 2004). In some specific malignancies, such as certain thoracic sarcomas (Le Loarer et al. 2015), biallelic inactivation of $B R G$ occurs at elevated frequencies. Although it was initially thought that in most cancers $B R G$ mutations were generally homozygous (Medina and Sanchez-Cespedes 2008; Medina et al. 2008), it has since been determined that, in many cancer types, a large number of mutations of $B R G$ are heterozygous, with many mutations clustering at conserved motifs of the ATPase domain. Accordingly, CRISPR-Cas9 tiling experiments have shown that the ATPase domain contains the most functionally important domain of BRG (Shi et al. 2015).

The ATPase domain of Snf2-like remodelers is composed of two conserved subdomains. The amino-terminal ATPase subdomain of BRG contains several residues highly conserved within the SF2 helicase superfamily (Jankowsky and Fairman 2007; Fairman-Williams et al. 2010). Based on crystal structures of homologous Snf2-like proteins (Durr et al. 2005; Thoma et al. 2005; Wollmann et al. 2011), many of these residues are predicted to contact ATP (Walker et al. 1982) or communicate the strain of ATP binding and hydrolysis to the site of DNA binding to exert mechanical force (Banroques et al. 2008), and are frequently mutated in a number of malignancies (Figs. 3 and 4). Some effects of these mutations have been characterized. For example, K785R and T910M, respectively, 
BAF and PBAF Complexes in Cancer

A

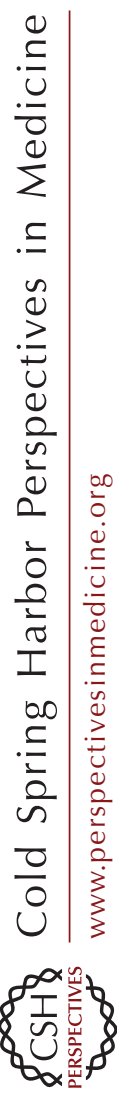

B
BAF/PBAF subunit alterations observed in cancer

Chromosome arm/focal deletion

Point mutation $\longrightarrow$

Gene fusion

Promoter hypermethylation
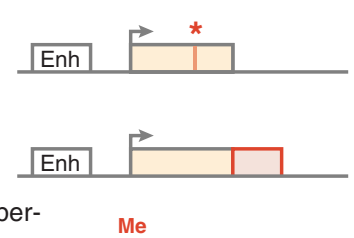

Additional mechanisms of altered BAF/PBAF subunit expression

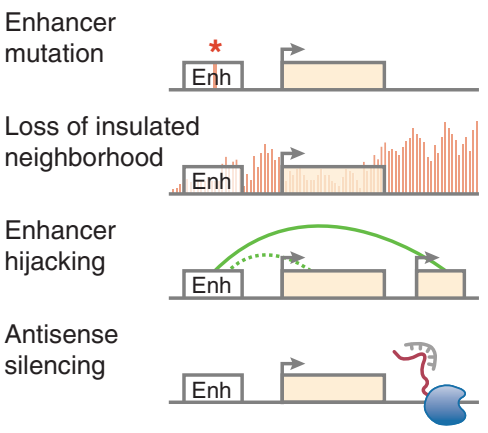

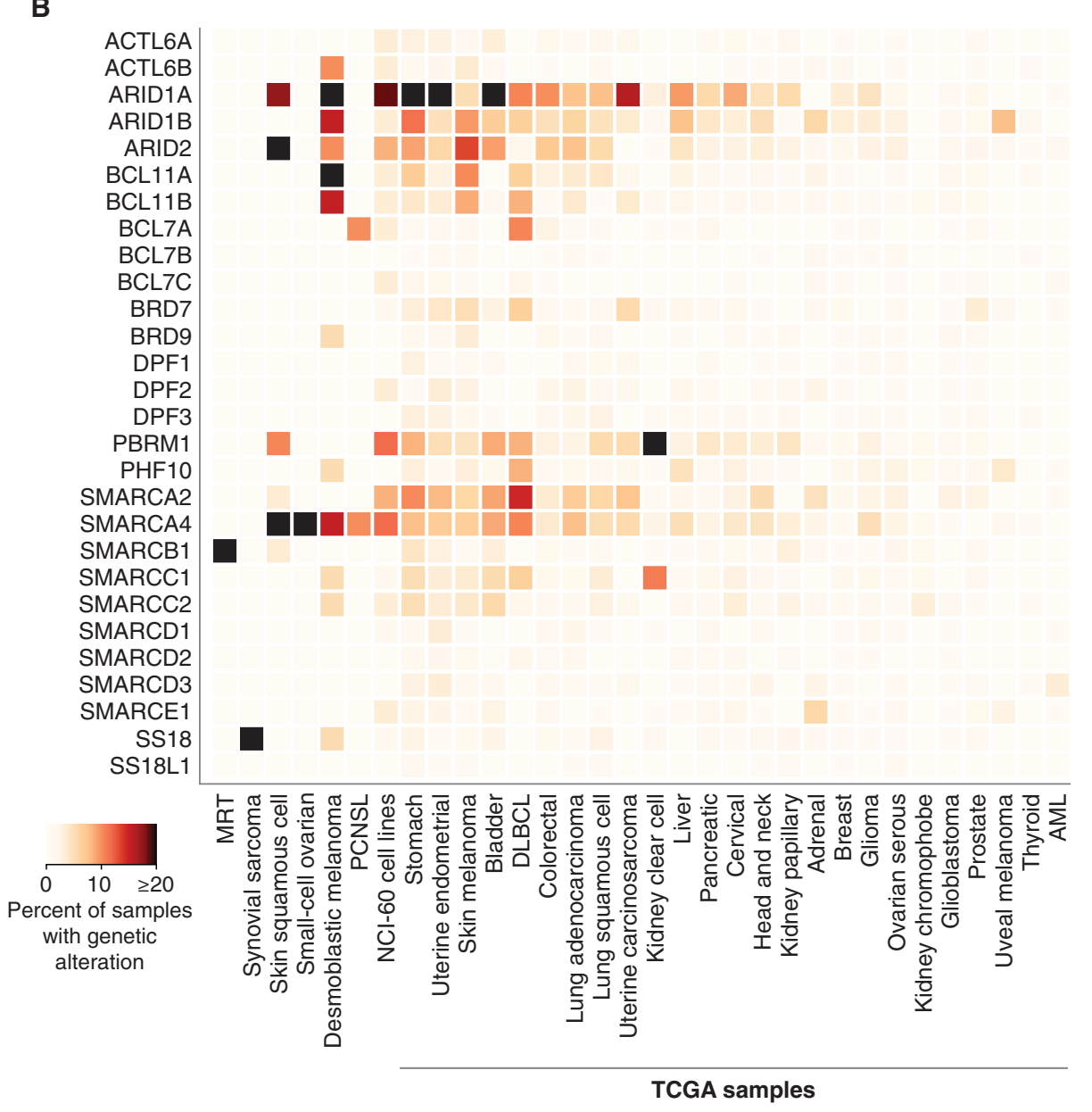

Figure 3. Mutations of BAF and PBAF subunits occur in subunit-specific patterns in cancer. $(A)$ (Left panel) Illustration of the different types of genetic and epigenetic disruptions that affect BAF/PBAF subunits in cancer. Deletion of chromosome arms or foci leads to loss of a subunit allele, point mutations alter coding sequence, gene fusions lead to altered function, and hypermethylation of promoters associated with loss of expression. (Legend continues on following page.) 
C. Hodges et al.

observed in melanoma (Hodis et al. 2012; The Cancer Genome Atlas 2015), medulloblastoma (Pugh et al. 2012), and several cancer cell lines, have severely reduced ATPase activity, leading to anaphase bridges and failure of topoisomerase IIa to bind DNA (Dykhuizen et al. 2013) (discussed in greater detail below). Adjacent residues are mutated in a number of different cancer types, suggesting that functional inactivation contributes to diverse malignancies. In other ATP-dependent remodelers, dominantnegative mutations result in phenotypes distinct from subunit deletion (Corona et al. 2004; Skene et al. 2014), suggesting that the particular mechanisms of inactivation may lead to different downstream effects.

Although the details remain murky, the carboxy-terminal subdomain of Snf2-like ATPases appears to cooperate with the amino-terminal subdomain to exert large-scale motions needed to translocate along DNA (Durr et al. 2005) but may also carry out some other uncharacterized activity. In the carboxy-terminal ATPase subdomain of BRG, R1192 is recurrently mutated in cancer of the stomach, liver, lung, melanoma, esophagus, and breast, as well as in gliomas (Figs. 3 and 4). Moreover, the homologous position is also mutated in BTAF1, CHD1, and ATRX in several different malignancies, suggesting this well-conserved position may be an Achilles' heel of Snf2-like remodelers. Other nearby mutations at conserved residues in Motif V of the carboxy-terminal subdomain severely compromise ATPase activity in the yeast SWI/SNF complex (Richmond and Peterson 1996; Smith and Peterson 2005). Although it is clear that commonly observed point mutations disrupt or completely abolish ATPase activity, a complete accounting of the downstream effects of these mutations in malignancy has not yet been performed.

BRM, the paralog of BRG that is not a subunit of the PBAF complex, also shows similar clustering of mutations at the amino- and carboxy-terminal helicase-like subdomains, but is much less frequently mutated in cancers (Figs. 3 and 4). Interestingly, several in-frame deletions in the QLQ domain of BRM have been observed in primary tumors and several cancer cell lines (Reinhold et al. 2012). BRM and homologs are regulators of splicing (Batsche et al. 2006; Tyagi et al. 2009; Waldholm et al. 2011; Patrick et al. 2015); however, the effects of its mutation on alternative splicing remain unknown.

\section{ARID1A in Uterine, Colorectal, Stomach, Bladder, and Other Cancers}

By far the most frequently disrupted BAF subunit is ARID1A (BAF250A; Fig. 2B). Large regions of both ARID1A and its paralog ARID1B are low-complexity sequences with unknown function. ARID1A and ARID1B both contain an ARID DNA-binding domain as well as a homologous domain of unknown function (currently designated DUF3518 in Pfam; Fig. 4). Although the function of this carboxy-terminal domain has not yet been described, it has been speculated to have ubiquitin ligase activity ( $\mathrm{Li}$ et al. 2010).

Among the earliest reports of the complex's tumor-suppressor role was the discovery that $\sim 50 \%$ of ovarian clear cell carcinomas and endometriosis-associated ovarian carcinomas contain inactivating ARID1A mutations (Jones et al. 2010; Wiegand et al. 2010). Mutations of ARID1A have since been observed at high frequency in a number of studies, including uterine

Figure 3. (Continued) (Right panel) Mechanisms leading to altered BAF/PBAF subunit expression in cancer may also include mutations in enhancers, loss of insulated neighborhoods leading to spreading of heterochromatin over BAF/PBAF genes, enhancer hijacking, and antisense silencing. (B) Heat map of the frequency of subunit alterations across cancer types ( frequency includes all nonsilent mutations, biallelic deletions, and gene fusions). Mutation frequencies for malignant rhabdoid tumor (MRT) and synovial sarcoma are inferred from available cytogenetic and mutation data, as described by works cited in the main text. All other data obtained from studies cited in the main text. PCNSL, Primary central nervous system lymphoma; DLBCL, diffuse large B-cell lymphoma; AML, acute myeloid leukemia. 


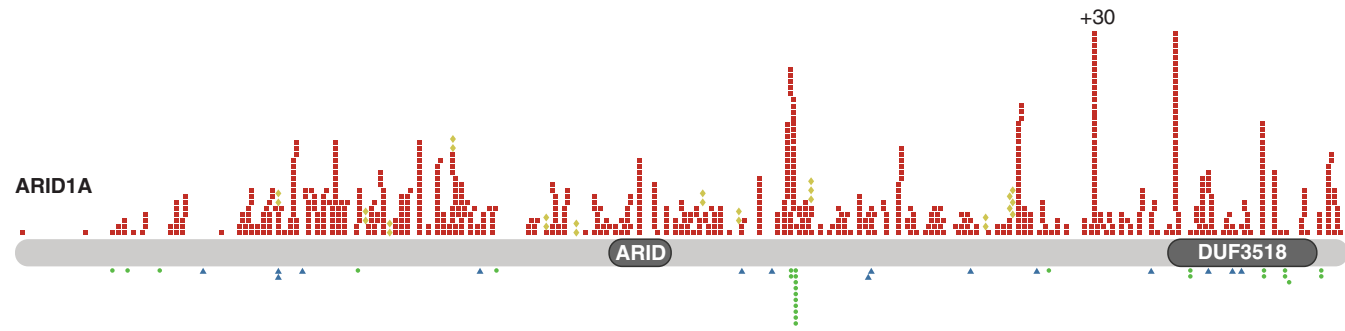

ARID1B

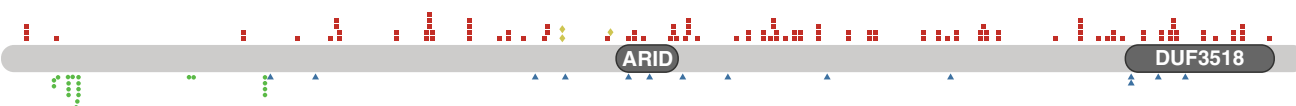

ARID2

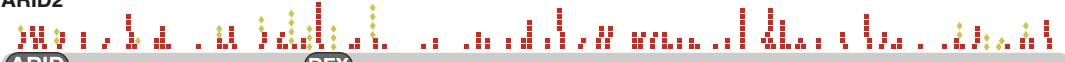
ARID RFX

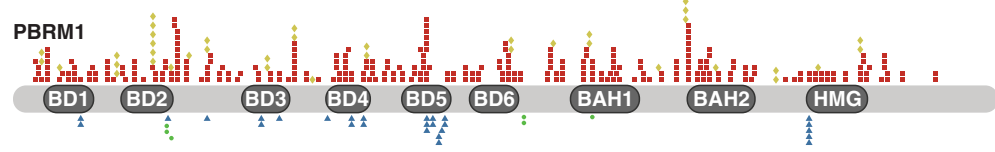

$1000 \mathrm{bp}$

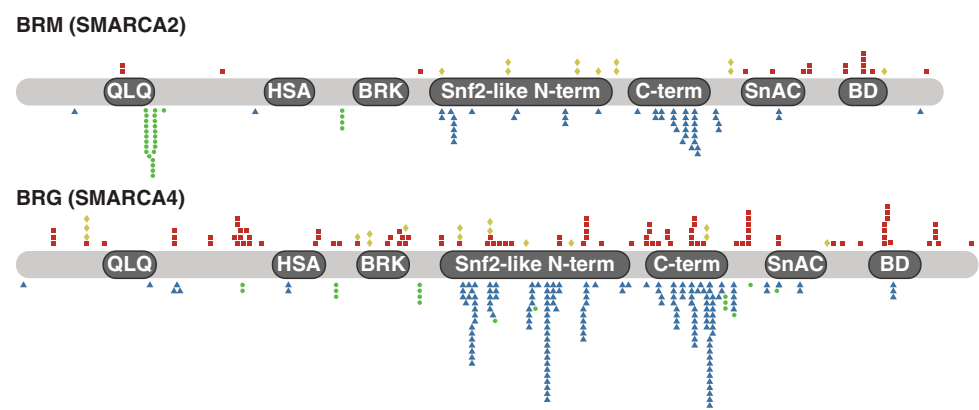

Legend

- Truncating mutations (frameshift, nonsense)

- Splice mutations

Missense mutations (high functional impact only)

- In-frame insertions/deletions Data: TCGA/CCLE/cBioPortal

Figure 4. Cancer mutations of BAF/PBAF subunits arise in characteristic patterns. ARID1A, ARID2, and PBRM1 are primarily affected by truncating mutations. The ATPases BRG and BRM show a high tendency for missense mutations at the conserved Snf2-like ATPase domains. Missense mutations predicted to have neutral, low, or medium functional impact are not shown because of the unknown nature of their effects and increased likelihood to be background mutations. N-term, Amino terminal; C-term, carboxy terminal.

endometrial carcinoma (34\%) (Kandoth et al. 2013), colorectal cancers (10\%) (The Cancer Genome Atlas 2012a), as well as cancers of the bladder (29\%) (Gui et al. 2011), stomach (34\%) (Wang et al. 2011a, 2014), cholangiocarcinomas (27\%) (Jiao et al. 2013), neuroblastomas (11\%) (Sausen et al. 2013), and pancreas ( 5\%) (Biankin et al. 2012). These recurrent loss-of-function mutations make ARID1A the premier tumorsuppressor subunit of the BAF complex; however, very little is known about the mechanisms of how this subunit contributes to malignancy.
Mutations of ARID1A are most frequently truncating mutations (frameshifts and nonsense mutations (Figs. 2C and 4), which may be degraded by nonsense-mediated decay. Although the ARID domain in mice is critical for the function of the protein, mutations in human cancer are not especially localized to the ARID domain; indeed no missense mutations expected to be of high functional impact have currently been reported in the ARID domain (Fig. 4). The few missense mutations present are generally predicted to have low or 
C. Hodges et al.

medium functional impact and are distributed uniformly over the gene. The hotspots of truncating mutations that occur are explained in part by frequent ARIDIA mutations arising in tumors with mutated DNA polymerase $\varepsilon$ $(P O L E)$. As a result of failed leading-strand proofreading during replication, POLE-mutated tumors often have huge numbers of $\mathrm{C}>\mathrm{T}$ transitions, many of which convert arginine codons (CGA) to stop codons (TGA) (Alexandrov et al. 2013). Biallelic inactivation of ARID1A does occur, but in many cases (particularly in gastric and endometrial cancer) mutations occur in only a single allele (Kandoth et al. 2013). However, hypermethylation of the ARID1A promoter has been observed in many breast cancers; hence, epigenetic silencing mechanisms are also common (Zhang et al. 2013).

In ovarian cancer, mutation of ARID1A frequently co-occurs with activating mutations of phosphatidylinositol 3-kinase $(P I 3 K)$. Interestingly, BRG binds the $\mathrm{PI} 3 \mathrm{~K}$ substrate $\mathrm{PIP}_{2}$ (phosphatidylinositol 4,5-bisphosphate), a phospholipid with several roles in signaling and a regulator of actin-related proteins. Binding of $\mathrm{PIP}_{2}$ by $\mathrm{Brg}$ regulates association of the complex with actin (Rando et al. 2002); therefore, activating mutations of PI3K may deplete $\mathrm{PIP}_{2}$, leading to altered BAF localization or function (Zhao et al. 1998). Mice with ARID1A/PI3K double mutations, but not mice with only a single ARIDIA or PI3K mutation, develop ovarian tumors with features similar to ovarian clear cell carcinoma (Chandler et al. 2015), suggesting the effects of $\mathrm{PIP}_{2}$ may be mediated through ARID1A-containing complexes and providing new insight into the cooperation of these two genes in cancer.

$A R I D 1 B$ is mutated in several malignancies and, like ARID1A, these mutations are also mostly truncating (Fig. 4). However, ARID1B mutations are not as frequent as those of ARID1A (Fig. 2C). This discrepancy may reflect important functional differences between these two genes, or may instead reflect ARID1B expression in fewer cell types. Interestingly, $A R I D 1 B$ has been identified as one of the most important genes involved in neurodevelopmental disorders (Santen et al. 2012; Tsurusaki et al. 2012; Deciphering Developmental Disorders Study 2015), further illustrating the relevance of combinatorial subunit assembly of BAF complexes to development and human diseases.

\section{PBRM1 in Clear Cell Renal Carcinoma}

PBRM1 (BAF180, Polybromo) is named for the presence of six bromodomains in the protein, and is a defining subunit of the PBAF complex. In renal clear cell carcinoma (ccRCC), mutation or loss of PBRM1 occurs in $\sim 41 \%$ of cases ( Varela et al. 2011), making it the second-most frequently mutated gene in ccRCC. Like ARID1A in other cancers, the majority of mutations of PBRM1 in ccRCC are truncating mutations (Figs. 2C and 4), which may not result in protein expression because of nonsense-mediated decay. However, many ccRCC cases have biallelic inactivation of $P B R M 1$, through loss of one allele via focal/chromosomal deletion at chromosome arm $3 \mathrm{p}$, and an inactivating mutation on the remaining allele. Furthermore, hypermethylation of the PBRM1 promoter is generally absent in ccRCC (Ibragimova et al. 2013), indicating that inactivation occurs primarily through mutation or deletion. Some tumors do contain missense mutations, and although their functional impacts remain uncertain, their presence suggests a degree of nonredundancy between these domains. Although most bromodomains bind acetylated lysines from histones, the role of PBRM1's bromodomains toward targeting of PBAF complexes remains uncertain.

In ccRCC, PBRM1 inactivation frequently coincides with mutation of the VHL (von Hippel-Lindau) tumor suppressor. Because of their close proximity on chromosome arm $3 \mathrm{p}$, focal and chromosome arm-level deletions frequently affect both of these genes simultaneously. However, the striking frequency of inactivating point mutations of PBRM1 alongside $V H L$ and BAP1 mutations suggests that joint inactivation of these genes may potentiate the oncogenic nature of these defects (Gerlinger et al. 2014).

Like PBRM1, ARID2 (BAF200) encodes another subunit dedicated to PBAF complexes. ARID2 is not a homolog of $A R I D 1 A / B$, but is 
instead mutually exclusive with $A R I D 1 A / B$, although the shared presence of an AT-rich interaction domain (ARID) in these three subunits suggests some common structural similarities. ARID2 is frequently mutated in other malignancies but is apparently not targeted in ccRCC as frequently as $P B R M 1$, suggesting that PBRM1 has an important and distinct functional role as a member of the PBAF complex in kidney cells. ARID2 has been reported to contribute to repression (Raab et al. 2015), and is frequently mutated in melanoma (Hodis et al. 2012; Ding et al. 2014; Lee et al. 2015), non-smallcell lung cancer (Manceau et al. 2013), as well as in $\sim 18 \%$ of hepatitis-associated hepatocellular carcinomas (Li et al. 2011). Moreover, the discovery of frequent joint inactivation of PBRM1, ARID2, and BAP1 in biliary-phenotype-displaying subtype of hepatic carcinomas (Fujimoto et al. 2015) suggests that in some contexts they may contribute to malignancy in a cooperative manner.

\section{SMARCB1 in Malignant Rhabdoid Tumors}

Perhaps the best-characterized example of a tumor-suppressor role for ATP-dependent chromatin remodeling comes from malignant rhabdoid tumors (MRTs). MRTs are rare but highly lethal childhood cancers that are caused by biallelic inactivation of SMARCB1 (BAF47, SNF5, or INI1), which occurs in nearly all cases (Versteege et al. 1998; Roberts et al. 2000). The classic loss of heterozygosity observed for SMARCBI leads to aberrant activation of Hedgehog-Gli and $\mathrm{Wnt} / \beta$-catenin pathways (Jagani et al. 2010; Mora-Blanco et al. 2014), and importantly, impairs the ability of BAF/PBAF complexes to regulate the placement and function of Polycomb repressive complexes. As a result of failure to oppose Polycomb, the repressive mark H3K27me3 accumulates at the tumor suppressor p16/INK4A (CDKN2A) locus (Wilson et al. 2010). The impaired opposition to Polycomb repression plays an important role in cancer, reminiscent of BAP/PBAP complexes throughout development in flies (Tamkun et al. 1992).

MRTs have remarkably stable diploid genomes except for deletions and mutations at chromosome 22q, where SMARCB1 is located (McKenna et al. 2008; McKenna and Roberts 2009; Lee et al. 2012). Exome sequencing also shows that these tumors have among the lowest mutational loads of any human tumor sequenced to date (Lawrence et al. 2014). Finally, ectopic expression of SMARCB1 reverses Polycomb silencing at the tumor suppressor $p 16 /$ INK4A locus, leading to cellular senescence (Oruetxebarria et al. 2004; Kia et al. 2008), indicating that these tumors are driven exclusively by epigenetic regulation (except for the original genetic inactivation of $S M A R C B 1$ ). In addition to MRTs, SMARCB1 appears to play a role in a number of cancers and other neoplastic disorders, including prostate cancer, epithelioid sarcomas, familial schwannomatosis, and renal medullary carcinomas (Roberts and Biegel 2009; Prensner et al. 2013). Biallelic inactivation of SMARCB1 has also been reported in 7\%$10 \%$ of Ewing sarcomas (Jahromi et al. 2012).

In mouse models, conditional deletion of SMARCB1 leads to T-cell lymphomas with short latency and $100 \%$ penetrance (Wang et al. 2011b), suggesting that SMARCB1 inactivation can cause fast transformation alone without other genetic changes, as observed in MRTs. Interestingly, rhabdoid tumors are not seen in mice with SMARCB1 inactivation, attesting to the tissue-specific and species-specific function of the complexes. Importantly, the pathogenesis of most human malignancies with $\mathrm{BAF} / \mathrm{PBAF}$ mutations may be different from that of MRTs. With the exception of some noteworthy examples described below, the majority of cancers bearing $\mathrm{BAF} / \mathrm{PBAF}$ subunit mutations are found in older age groups, in which tumors have long latencies, are highly mutated, and are genomically unstable. Thus, the low mutation rates observed in MRTs may be because of the extremely short latency between biallelic inactivation and transformation, which may not allow accumulation of mutations resulting from impairment of the complex's other functions.

\section{SS18 in Synovial Sarcoma}

Synovial sarcoma is an aggressive, poorly differentiated, stem-cell-like soft-tissue malignancy that typically arises in the extremities of young 
C. Hodges et al.

adults. The hallmark of synovial sarcoma is a highly characteristic translocation of chromosomes 18 and $\mathrm{X}$, which fuses the dedicated BAF subunit SS18 (Middeljans et al. 2012) to the SSX fusion partner on the X chromosome (Crew et al. 1995; Naka et al. 2010). This fusion occurs in nearly all cases and in some cases is the only known cytogenetic abnormality. Despite the continued existence of the remaining wildtype SS18 allele and unaltered BAF47 alleles, the SS18-SSX fusion is preferentially assembled into the BAF complex concomitant with complete loss of BAF47 from the complex. BAF complexes containing the SS18-SSX fusion are retargeted to oncogenic loci such as SOX2 and $P A X 6$, where removal of the repressive histone mark $\mathrm{H} 3 \mathrm{~K} 27 \mathrm{me} 3$ results in transformation (Kadoch and Crabtree 2013).

Forced overexpression of wild-type SS18, or shRNA-mediated knockdown of the SS18SSX fusion, is sufficient to reverse oncogenic BAF subunit composition. Reversion leads to increased levels of $\mathrm{H} 3 \mathrm{~K} 27 \mathrm{me} 3$ at SOX2 and other oncogenic loci, and loss of proliferation (Kadoch and Crabtree 2013), indicating that transformation is maintained through epigenetic mechanisms. The reversible and remarkably specific pathogenesis of synovial sarcoma suggests that this tumor may be an attractive candidate for development of therapeutics.

A number of similarities exist between synovial sarcoma and MRTs. They are both childhood malignancies driven by a defining alteration of a single BAF subunit, and senescence can be achieved by repair of the affected subunit. Moreover, SMARCB1 activity is abolished in both cancers, albeit through different mechanisms. However, in contrast to MRTs, which transform by failing to oppose Polycomb activity at $p 16 / I N K 4 A$, the genetic dominance of the SS18-SSX fusion in synovial sarcoma arises from its preferential assembly into BAF complexes, and its apparent ability to retarget the complex and oppose Polycomb at oncogenic loci (Kadoch and Crabtree 2013).

BAF53A and the Role of Nuclear Actin/ARPs

$B A F 53 A$ (ACTL6A) is an ARP and a subunit of $\mathrm{BAF} / \mathrm{PBAF}$ complexes that is rarely mutated in cancer. Instead, BAF53A frequently undergoes amplification in squamous cell malignancies from many different tissues of origin. BAF53A is required for maintenance of hematopoietic stem cell identity (Krasteva et al. 2012), and also maintains a progenitor state in epidermal cells by repressing KLF4, an activator of differentiation (Bao et al. 2013). Recent work has also shown that BAF53A is a target of miR-206, a microRNA missing in rhabdomyosarcomas (RMS). The resulting up-regulation of $B A F 53 A$ in RMS cells contributes to the failure of myogenic cells to properly differentiate (Taulli et al. 2014), whereas its silencing inhibits proliferation of RMS cells, suggesting that BAF53A promotes proliferation and interferes with differentiation. Therefore, it is appealing to speculate that BAF53A may generally have oncogenic or mitogenic role in many cell types, perhaps based on interaction with the BRG/BRM helicase-SANT-associated (HSA) domain (Zhao et al. 1998; Rando et al. 2002; Szerlong et al. 2008). Ablation of the HSA domain from Sth1, the ATPase of RSC in yeast, causes the specific loss of ARPs from the complex, and a reduction in the activity of the ATPase.

ARPs are genetically essential subunits of SWI/SNF-like remodelers (Shen et al. 2003; $\mathrm{Wu}$ et al. 2007), and the interaction of actin and ARPs with the HSA domain from Snf2like ATPases has long been thought to regulate their activity. Although complexes reconstituted without actin or ARPs can achieve remodeling activity comparable to intact complexes in vitro (Phelan et al. 1999), BAF53A/B is required for BAF function in vivo. The crystal structure of the Snf2 HSA domain with Arp7 and Arp9 shows that actin filament formation is unlikely because of the incompatible position adopted by the ARPs (Schubert et al. 2013). Thus, rather than binding filamentous actin, the ARPs in the complex may instead modulate ATPase activity or the coupling of ATP hydrolysis to remodeling activity.

Important structural differences exist between the yeast complexes and human complexes (Zhao et al. 1998). In yeast, both the SWI/ SNF and RSC complexes contain Arp7 and Arp9 as obligate heterodimers (Szerlong et al. 
2003), but lack actin itself (Cairns et al. 1998; Peterson et al. 1998). In contrast, BAF and PBAF complexes contain BAF53A/B and actin (Zhao et al. 1998). Therefore, it remains unclear whether the structures from yeast also apply directly to the mammalian complexes. As a result, it remains unknown how excess BAF53A may affect the activity of BAF and PBAF complexes.

\section{NONTRANSCRIPTIONAL ROLES OF BAF/PBAF COMPLEXES IN CANCER}

\section{Involvement in DNA Repair and Chromosome Stability}

In addition to their well-established roles as epigenetic regulators described above, $\mathrm{BAF} / \mathrm{PBAF}$ complexes have several nontranscriptional roles that also contribute to malignancy. One nontranscriptional role in cancer is found in DNArepair pathways. Various mechanisms have been proposed for recruitment of BAF/PBAF complexes to sites of DNA damage, including ATM-/ATR-dependent phosphorylation of BAF170 (Peng et al. 2009), and a direct interaction between $\gamma$-H2A.X and the BRG bromodomain (Lee et al. 2010). In addition, evidence now points to roles for BAF and PBAF in both NHEJ and HR pathways (Ogiwara et al. 2011; Watanabe et al. 2014; Brownlee et al. 2015; Qi et al. 2015). Therefore, in humans, BAF and PBAF complexes may help protect genomic integrity similar to the INO80 complex in budding yeast (Gerhold et al. 2015), which interestingly is not frequently mutated in cancer.

In addition to well-established pathways of DNA repair, PBAF complexes have other important roles for maintaining genomic stability. PBRM1 plays a critical role in sister chromatid cohesion, in which misregulation leads to genome instability, anaphase bridges, and aneuploidy (Brownlee et al. 2014). PBRM1 also plays a role in repriming stalled replication forks similar to yeast RSC complexes (Askree et al. 2004). Stalled replication forks are common sites of DNA damage, providing another important mechanism for ensuring genome integrity (Niimi et al. 2012). Recently, roles for PBAF but not BAF have been identified in DNA-damageinduced transcriptional repression that involves PRC1/2 subunits (Kakarougkas et al. 2014), and ubiquitination of PCNA following DNA damage (Niimi et al. 2015).

$\mathrm{BAF}$ and PBAF subunits occupy regions that are critical for chromosome organization, such as the binding sites of CTCF (CCCTC-binding factor), cohesins, lamin, and replication origins (Euskirchen et al. 2011). In addition to the loop anchor sites formed by CTCF and cohesins, which appear to be master regulators of topological domains in stem cells and cancer cell lines (Kagey et al. 2010; Dixon et al. 2012; Yan et al. 2013; Dowen et al. 2014; Ji et al. 2015), several other chromatin organizational elements have been identified in eukaryotes, such as tRNA genes (Kirkland et al. 2013), repetitive elements (Lunyak et al. 2007), transposons (Lippman et al. 2004), and PRC1-binding sites (Bantignies et al. 2011; Schoenfelder et al. 2015; Wani et al. 2016). Chromatin architectural sites are often subject to epigenetic regulation (Bell and Felsenfeld 2000; Wang et al. 2012) and show significant BAF and PBAF enrichment (Euskirchen et al. 2011), suggesting that BAF and PBAF may play important roles in regulating overall chromatin architecture.

\section{Synergy between BAF and Topoisomerase Function}

Topoisomerases require nucleosome-free DNA (Sperling et al. 2011), and mutants of BRG that impair ATPase activity induce loss of topoisomerase IIa (TOP2A) binding to DNA, leading to topological defects, anaphase bridges, and partial arrest at the relatively uncharacterized decatenation checkpoint (Dykhuizen et al. 2013). Lung cancer cell lines with $B R G$ mutations show increased sensitivity to topoisomerase II inhibitors when EZH2 is also inhibited (Fillmore et al. 2015), suggesting interplay between BAF, TOP2A, and PRC2 in the maintenance of chromatin topology. The importance of BAF's activity toward TOP2A function was recently underlined by the observation that mutations in BAF subunits predict responses to treatment with TOP2A inhibitors (Pang et al. 2015; Wijdeven 
C. Hodges et al.

et al. 2015). Importantly, the mechanism of opposition to EZH2 consists of more than opposing its methyltransferase activity (Kim et al. 2015), and may underlie an aspect of BAF's tumor-suppressor function with significant clinical importance.

\section{TARGETING TUMORS WITH BAF/PBAF DEFICIENCIES}

Recent reports suggest new approaches for targeting tumors with altered BAF/PBAF complexes based on synthetic lethality. In several tumor types, inactivation of one BAF/PBAF subunit induces dependency on the continued expression of that subunit's paralog. For example, tumors with $B R G$ mutations frequently depend on the expression of BRM (Aguirre et al. 2014; Wilson et al. 2014), whereas tumors with ARID1A mutations often depend on ARID1B (Helming et al. 2014). Targeting these genetic dependencies represents a novel strategy to attack these tumors. Additionally, loss-offunction of BAF/PBAF subunits may lead to increased Polycomb activity; therefore, inhibition of Polycomb silencing may be beneficial for patients with tumors bearing BAF/PBAF deficiencies. However, the effectiveness of these approaches may depend greatly on the downstream consequences of BAF/PBAF dysfunction within each cell type. For example, PRC2 inhibition may be more beneficial for MRTs than for synovial sarcoma, based on the molecular mechanisms of transformation described above, illustrating the continuing need to examine the epigenetic mechanisms within each tumor type.

\section{PERSPECTIVE AND CLOSING REMARKS}

Although abundant evidence indicates that BAF and PBAF defects contribute to malignancy by altering the epigenetic landscape to regulate transcription, many lines of evidence indicate that these defects have pleiotropic effects, because complexes participate in a number of other important chromatin regulatory processes. In addition to their roles in regulating transcrip-
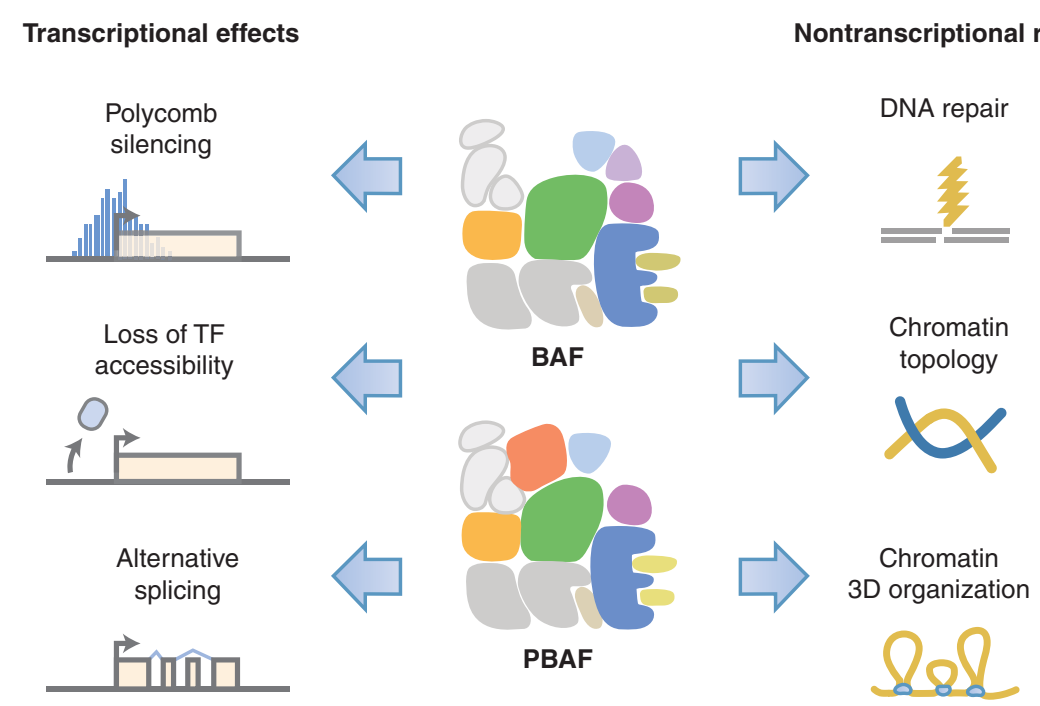

Figure 5. The effects of BAF and PBAF dysfunction in cancer. Dysfunctional BAF/PBAF complexes have been shown to deregulate Polycomb silencing of key tumor suppressors and oncogenes. In model systems, disruption of BAF- and PBAF-like complexes also affects DNA accessibility for transcription and other regulatory factors, and impacts splicing patterns. Given the conserved regulatory roles for BAF- and PBAF-like remodelers in DNA repair, maintenance of chromatin topology and 3D architecture, we anticipate that whole-genome sequencing and new techniques to examine 3D-chromatin architecture may reveal new roles for the complex in addition to its well-defined role as a transcriptional regulator. 
tion, a body of work from cancer cell lines and model organisms indicates that BAF- and PBAF-like complexes contribute to several other processes, ranging from DNA recombination and repair to maintenance of $3 \mathrm{D}$ chromatin architecture and topology (Fig. 5).

Their numerous roles underscore the fact that the epigenetic state is more than simply a regulatory framework for transcription, but instead represents the sum physicochemical state of the genetic material, which impacts a large number of processes. As a result, the fundamental role of any given BAF and PBAF alteration in cancer is likely to be unique to each cancer type, and may reflect the idiosyncratic processes that drive each malignancy (whether oncogene addiction, autocrine signaling, mutagen exposure, chromosomal instability, etc.). Whole-genome sequencing and various new techniques to examine 3D-chromatin architecture may offer substantial insight into the full breadth of the effects of BAF and PBAF dysfunction, and reveal their diverse contributions toward oncogenesis and tumor biology.

\section{ACKNOWLEDGMENTS}

Figures and results reviewed here are based in part on data generated by the The Cancer Genome Atlas Research Network and hosted on cBioPortal (Cerami et al. 2012; Gao et al. 2013). This work is supported by a National Cancer Institute (NCI) career transition award K99CA187565 (C.H.), NCI Grant T32CA009151 (J.G.K.), National Institutes of Health (NIH) Grants R37NS046789 and R01CA163915 (G.R.C.), and the Howard Hughes Medical Institute (G.R.C.).

\section{REFERENCES}

Aguirre AJ, Jagani Z, Wang Z, Garraway LA, Hahn WC Roberts CW, Hoffman GR, Rahal R, Buxton F, Xiang $\mathrm{K}$, et al. 2014. Functional epigenetics approach identifies BRM/SMARCA2 as a critical synthetic lethal target in BRG1-deficient cancers. Nat Med 111: 3128-3133.

Aizawa H, Hu SC, Bobb K, Balakrishnan K, Ince G, Gurevich I, Cowan M, Ghosh A. 2004. Dendrite development regulated by CREST, a calcium-regulated transcriptional activator. Science 303: 197-202.
Alexandrov LB, Nik-Zainal S, Wedge DC, Aparicio SA, Behjati S, Biankin AV, Bignell GR, Bolli N, Borg A, BorresenDale AL, et al. 2013. Signatures of mutational processes in human cancer. Nature 500: 415-421.

Armstrong JA, Papoulas O, Daubresse G, Sperling AS, Lis JT, Scott MP, Tamkun JW. 2002. The Drosophila BRM complex facilitates global transcription by RNA polymerase II. EMBO J 21: 5245-5254.

Askree SH, Yehuda T, Smolikov S, Gurevich R, Hawk J, Coker C, Krauskopf A, Kupiec M, McEachern MJ. 2004. A genome-wide screen for Saccharomyces cerevisiae deletion mutants that affect telomere length. Proc Natl Acad Sci 101: 8658-8663.

Asturias FJ, Chung WH, Kornberg RD, Lorch Y. 2002. Structural analysis of the RSC chromatin-remodeling complex. Proc Natl Acad Sci 99: 13477-13480.

Baetz KK, Krogan NJ, Emili A, Greenblatt J, Hieter P. 2004. The ctf13-30/CTF13 genomic haploinsufficiency modifier screen identifies the yeast chromatin remodeling complex RSC, which is required for the establishment of sister chromatid cohesion. Mol Cell Biol 24: 12321244.

Bajpai R, Chen DA, Rada-Iglesias A, Zhang J, Xiong Y, Helms J, Chang CP, Zhao Y, Swigut T, Wysocka J. 2010. CHD7 cooperates with PBAF to control multipotent neural crest formation. Nature 463: 958-962.

Balbiani E. 1881. Sur la structure du noyau des cellules salivaires chez les larves de Chironomus [On the structure of salivary cell nuclei in Chironomus larvae]. Zool Anz 4: 662-667.

Banroques J, Cordin O, Doere M, Linder P, Tanner NK. 2008. A conserved phenylalanine of motif IV in superfamily 2 helicases is required for cooperative, ATP-dependent binding of RNA substrates in DEAD-box proteins. Mol Cell Biol 28: 3359-3371.

Bantignies F, Roure V, Comet I, Leblanc B, Schuettengruber B, Bonnet J, Tixier V, Mas A, Cavalli G. 2011. Polycombdependent regulatory contacts between distant Hox loci in Drosophila. Cell 144: 214-226.

Bao X, Tang J, Lopez-Pajares V, Tao S, Qu K, Crabtree GR, Khavari PA. 2013. ACTL6a enforces the epidermal progenitor state by suppressing SWI/SNF-dependent induction of KLF4. Cell Stem Cell 12: 193-203.

Bao X, Rubin AJ, Qu K, Zhang J, Giresi PG, Chang HY, Khavari PA. 2015. A novel ATAC-seq approach reveals lineage-specific reinforcement of the open chromatin landscape via cooperation between BAF and p63. Genome Biol 16: 284.

Batsche E, Yaniv M, Muchardt C. 2006. The human SWI/ SNF subunit Brm is a regulator of alternative splicing. Nat Struct Mol Biol 13: 22-29.

Becker PB, Horz W. 2002. ATP-dependent nucleosome remodeling. Annu Rev Biochem 71: 247-273.

Bell AC, Felsenfeld G. 2000. Methylation of a CTCF-dependent boundary controls imprinted expression of the Igf2 gene. Nature 405: 482-485.

Biankin AV, Waddell N, Kassahn KS, Gingras MC, Muthuswamy LB, Johns AL, Miller DK, Wilson PJ, Patch AM, $\mathrm{Wu}$ J, et al. 2012. Pancreatic cancer genomes reveal aberrations in axon guidance pathway genes. Nature 491: 399-405. 
C. Hodges et al.

Birrell GW, Giaever G, Chu AM, Davis RW, Brown JM. 2001 A genome-wide screen in Saccharomyces cerevisiae for genes affecting UV radiation sensitivity. Proc Natl Acad Sci 98: 12608-12613.

Bouazoune K, Brehm A. 2006. ATP-dependent chromatin remodeling complexes in Drosophila. Chromosome Res 14: 433-449.

Brownlee PM, Chambers AL, Cloney R, Bianchi A, Downs JA. 2014. BAF180 promotes cohesion and prevents genome instability and aneuploidy. Cell Rep 6: 973-981.

Brownlee PM, Meisenberg C, Downs JA. 2015. The SWI/ SNF chromatin remodelling complex: Its role in maintaining genome stability and preventing tumourigenesis. DNA Repair (Amst) 32: 127-133.

Cairns BR, Kim YJ, Sayre MH, Laurent BC, Kornberg RD. 1994. A multisubunit complex containing the SWI1/ ADR6, SWI2/SNF2, SWI3, SNF5, and SNF6 gene products isolated from yeast. Proc Natl Acad Sci 91: 19501954.

Cairns BR, Lorch Y, Li Y, Zhang M, Lacomis L, ErdjumentBromage H, Tempst P, Du J, Laurent B, Kornberg RD. 1996. RSC, an essential, abundant chromatin-remodeling complex. Cell 87: 1249-1260.

Cairns BR, Erdjument-Bromage H, Tempst P, Winston F, Kornberg RD. 1998. Two actin-related proteins are shared functional components of the chromatin-remodeling complexes RSC and SWI/SNF. Mol Cell 2: 639-651.

Cairns BR, Schlichter A, Erdjument-Bromage H, Tempst P, Kornberg RD, Winston F. 1999. Two functionally distinct forms of the RSC nucleosome-remodeling complex, containing essential AT hook, BAH, and bromodomains. Mol Cell 4: 715-723.

Carlson M, Osmond BC, Botstein D. 1981. Mutants of yeast defective in sucrose utilization. Genetics 98: 25-40.

Cerami E, Gao J, Dogrusoz U, Gross BE, Sumer SO, Aksoy BA, Jacobsen A, Byrne CJ, Heuer ML, Larsson E, et al. 2012. The cBio cancer genomics portal: An open platform for exploring multidimensional cancer genomics data. Cancer Discov 2: 401-404.

Chaban Y, Ezeokonkwo C, Chung WH, Zhang F, Kornberg RD, Maier-Davis B, Lorch Y, Asturias FJ. 2008. Structure of a RSC-nucleosome complex and insights into chromatin remodeling. Nat Struct Mol Biol 15: 1272-1277.

Chai B, Huang J, Cairns BR, Laurent BC. 2005. Distinct roles for the RSC and Swi/Snf ATP-dependent chromatin remodelers in DNA double-strand break repair. Genes Dev 19: $1656-1661$.

Chalkley GE, Moshkin YM, Langenberg K, Bezstarosti K, Blastyak A, Gyurkovics H, Demmers JA, Verrijzer CP. 2008. The transcriptional coactivator SAYP is a trithorax group signature subunit of the PBAP chromatin remodeling complex. Mol Cell Biol 28: 2920-2929.

Chandler RL, Damrauer JS, Raab JR, Schisler JC, Wilkerson MD, Didion JP, Starmer J, Serber D, Yee D, Xiong J, et al. 2015. Coexistent ARID1A-PIK3CA mutations promote ovarian clear-cell tumorigenesis through pro-tumorigenic inflammatory cytokine signalling. Nat Commun 6: 6118.

Chevenet F, Brun C, Banuls AL, Jacq B, Christen R. 2006. TreeDyn: Towards dynamic graphics and annotations for analyses of trees. BMC Bioinformatics 7: 439.
Clapier CR, Cairns BR. 2009. The biology of chromatin remodeling complexes. Annu Rev Biochem 78: 273-304.

Collins RT, Furukawa T, Tanese N, Treisman JE. 1999. Osa associates with the Brahma chromatin remodeling complex and promotes the activation of some target genes. EMBO J 18: 7029-7040.

Corona DF, Armstrong JA, Tamkun JW. 2004. Genetic and cytological analysis of Drosophila chromatin-remodeling factors. Methods Enzymol 377: 70-85.

Crew AJ, Clark J, Fisher C, Gill S, Grimer R, Chand A, Shipley J, Gusterson BA, Cooper CS. 1995. Fusion of SYT to two genes, SSX1 and SSX2, encoding proteins with homology to the Kruppel-associated box in human synovial sarcoma. EMBO J 14: 2333-2340.

Crosby MA, Miller C, Alon T, Watson KL, Verrijzer CP, Goldman-Levi R, Zak NB. 1999. The trithorax group gene moira encodes a Brahma-associated putative chromatin-remodeling factor in Drosophila melanogaster. Mol Cell Biol 19: 1159-1170.

Davoli T, Xu AW, Mengwasser KE, Sack LM, Yoon JC, Park PJ, Elledge SJ. 2013. Cumulative haploinsufficiency and triplosensitivity drive aneuploidy patterns and shape the cancer genome. Cell 155: 948-962.

Dechassa ML, Zhang B, Horowitz-Scherer R, Persinger J, Woodcock CL, Peterson CL, Bartholomew B. 2008. Architecture of the SWI/SNF-nucleosome complex. Mol Cell Biol 28: 6010-6021.

Deciphering Developmental Disorders Study. 2015. Largescale discovery of novel genetic causes of developmental disorders. Nature 519: 223-228.

Dhillon N, Raab J, Guzzo J, Szyjka SJ, Gangadharan S, Aparicio OM, Andrews B, Kamakaka RT. 2009. DNA polymerase epsilon, acetylases and remodellers cooperate to form a specialized chromatin structure at a tRNA insulator. $E M B O J$ 28: 2583-2600.

Ding L, Kim M, Kanchi KL, Dees ND, Lu C, Griffith M, Fenstermacher D, Sung H, Miller CA, Goetz B, et al. 2014. Clonal architectures and driver mutations in metastatic melanomas. PLoS ONE 9: e111153.

Dixon JR, Selvaraj S, Yue F, Kim A, Li Y, Shen Y, Hu M, Liu JS, Ren B. 2012. Topological domains in mammalian genomes identified by analysis of chromatin interactions. Nature 485: 376-380.

Dowen JM, Fan ZP, Hnisz D, Ren G, Abraham BJ, Zhang LN, Weintraub AS, Schuijers J, Lee TI, Zhao K, et al. 2014. Control of cell identity genes occurs in insulated neighborhoods in mammalian chromosomes. Cell 159: $374-$ 387.

Dror V, Winston F. 2004. The Swi/Snf chromatin remodeling complex is required for ribosomal DNA and telomeric silencing in Saccharomyces cerevisiae. Mol Cell Biol 24: 8227-8235.

Dunaief JL, Strober BE, Guha S, Khavari PA, Alin K, Luban J, Begemann M, Crabtree GR, Goff SP. 1994. The retinoblastoma protein and BRG1 form a complex and cooperate to induce cell cycle arrest. Cell 79: 119-130.

Durr H, Korner C, Muller M, Hickmann V, Hopfner KP. 2005. X-ray structures of the Sulfolobus solfataricus SWI2/SNF2 ATPase core and its complex with DNA. Cell 121: 363-373. 
Dykhuizen EC, Hargreaves DC, Miller EL, Cui K, Korshunov A, Kool M, Pfister S, Cho YJ, Zhao K, Crabtree GR. 2013. BAF complexes facilitate decatenation of DNA by topoisomerase II $\alpha$. Nature 497: 624-627.

Estruch F, Carlson M. 1990. SNF6 encodes a nuclear protein that is required for expression of many genes in Saccharomyces cerevisiae. Mol Cell Biol 10: 2544-2553.

Euskirchen GM, Auerbach RK, Davidov E, Gianoulis TA, Zhong G, Rozowsky J, Bhardwaj N, Gerstein MB, Snyder M. 2011. Diverse roles and interactions of the SWI/SNF chromatin remodeling complex revealed using global approaches. PLoS Genet 7: e1002008.

Fairman-Williams ME, Guenther UP, Jankowsky E. 2010. SF1 and SF2 helicases: Family matters. Curr Opin Struct Biol 20: 313-324.

Fillmore CM, Xu C, Desai PT, Berry JM, Rowbotham SP, Lin YJ, Zhang H, Marquez VE, Hammerman PS, Wong KK, et al. 2015. EZH2 inhibition sensitizes BRG1 and EGFR mutant lung tumours to TopoII inhibitors. Nature 520: 239-242.

Fujimoto A, Furuta M, Shiraishi Y, Gotoh K, Kawakami Y, Arihiro K, Nakamura T, Ueno M, Ariizumi S, Nguyen $\mathrm{HH}$, et al. 2015. Whole-genome mutational landscape of liver cancers displaying biliary phenotype reveals hepatitis impact and molecular diversity. Nat Commun 6: 6120.

Gao J, Aksoy BA, Dogrusoz U, Dresdner G, Gross B, Sumer SO, Sun Y, Jacobsen A, Sinha R, Larsson E, et al. 2013. Integrative analysis of complex cancer genomics and clinical profiles using the cBioPortal. Sci Signal 6: pl1.

Gerhold CB, Hauer MH, Gasser SM. 2015. INO80-C and SWR-C: Guardians of the genome. J Mol Biol 427: $637-$ 651.

Gerlinger M, Horswell S, Larkin J, Rowan AJ, Salm MP, Varela I, Fisher R, McGranahan N, Matthews N, Santos CR, et al. 2014. Genomic architecture and evolution of clear cell renal cell carcinomas defined by multiregion sequencing. Nat Genet 46: 225-233.

Gong F, Fahy D, Smerdon MJ. 2006. Rad4-Rad23 interaction with SWI/SNF links ATP-dependent chromatin remodeling with nucleotide excision repair. Nat Struct Mol Biol 13: $902-907$.

Gui Y, Guo G, Huang Y, Hu X, Tang A, Gao S, Wu R, Chen C, Li X, Zhou L, et al. 2011. Frequent mutations of chromatin remodeling genes in transitional cell carcinoma of the bladder. Nat Genet 43: 875-878

Hartley PD, Madhani HD. 2009. Mechanisms that specify promoter nucleosome location and identity. Cell 137: $445-458$.

He J, Xuan T, Xin T, An H, Wang J, Zhao G, Li M. 2014. Evidence for chromatin-remodeling complex PBAP-controlled maintenance of the Drosophila ovarian germline stem cells. PLoS ONE 9: e103473.

Hedges SB, Dudley J, Kumar S. 2006. TimeTree: A public knowledge-base of divergence times among organisms. Bioinformatics 22: 2971-2972.

Helming KC, Wang X, Wilson BG, Vazquez F, Haswell JR, Manchester HE, Kim Y, Kryukov GV, Ghandi M. 2014. ARID1B is a specific vulnerability in ARID1A-mutant cancers. Nat Med 20: 251-254.
Ho L, Crabtree GR. 2010. Chromatin remodelling during development. Nature 463: 474-484.

Ho L, Jothi R, Ronan JL, Cui K, Zhao K, Crabtree GR. 2009a. An embryonic stem cell chromatin remodeling complex, esBAF, is an essential component of the core pluripotency transcriptional network. Proc Natl Acad Sci 106: 51875191.

Ho L, Ronan JL, Wu J, Staahl BT, Chen L, Kuo A, Lessard J, Nesvizhskii AI, Ranish J, Crabtree GR. 2009b. An embryonic stem cell chromatin remodeling complex, esBAF, is essential for embryonic stem cell self-renewal and pluripotency. Proc Natl Acad Sci 106: 5181-5186.

Ho L, Miller EL, Ronan JL, Ho WQ, Jothi R, Crabtree GR. 2011. esBAF facilitates pluripotency by conditioning the genome for LIF/STAT3 signalling and by regulating polycomb function. Nat Cell Biol 13: 903-913.

Hodis E, Watson IR, Kryukov GV, Arold ST, Imielinski M, Theurillat JP, Nickerson E, Auclair D, Li L, Place C, et al. 2012. A landscape of driver mutations in melanoma. Cell 150: $251-263$.

Hsu JM, Huang J, Meluh PB, Laurent BC. 2003. The yeast RSC chromatin-remodeling complex is required for kinetochore function in chromosome segregation. Mol Cell Biol 23: 3202-3215.

Ibragimova I, Maradeo ME, Dulaimi E, Cairns P. 2013. Aberrant promoter hypermethylation of PBRM1, BAP1, SETD2, KDM6A and other chromatin-modifying genes is absent or rare in clear cell RCC. Epigenetics 8: 486-493.

Imielinski M, Berger AH, Hammerman PS, Hernandez B, Pugh TJ, Hodis E, Cho J, Suh J, Capelletti M, Sivachenko A, et al. 2012. Mapping the hallmarks of lung adenocarcinoma with massively parallel sequencing. Cell 150: 1107-1120.

Jagani Z, Mora-Blanco EL, Sansam CG, McKenna ES, Wilson B, Chen D, Klekota J, Tamayo P, Nguyen PT, Tolstorukov M, et al. 2010. Loss of the tumor suppressor Snf5 leads to aberrant activation of the Hedgehog-Gli pathway. Nat Med 16: 1429-1433.

Jahromi MS, Putnam AR, Druzgal C, Wright J, SprakerPerlman H, Kinsey M, Zhou H, Boucher KM, Randall RL, Jones KB, et al. 2012. Molecular inversion probe analysis detects novel copy number alterations in Ewing sarcoma. Cancer Genet 205: 391-404.

Jankowsky E, Fairman ME. 2007. RNA helicases-One fold for many functions. Curr Opin Struct Biol 17: 316-324.

Jelinic P, Mueller JJ, Olvera N, Dao F, Scott SN, Shah R, Gao J, Schultz N, Gonen M, Soslow RA, et al. 2014. Recurrent SMARCA4 mutations in small cell carcinoma of the ovary. Nat Genet 46: 424-426.

Ji X, Dadon DB, Powell BE, Fan ZP, Borges-Rivera D, Shachar S, Weintraub AS, Hnisz D, Pegoraro G, Lee TI, et al. 2015. 3D chromosome regulatory landscape of human pluripotent cells. Cell Stem Cell 18: 262-275.

Jiao Y, Pawlik TM, Anders RA, Selaru FM, Streppel MM, Lucas DJ, Niknafs N, Guthrie VB, Maitra A, Argani P, et al. 2013. Exome sequencing identifies frequent inactivating mutations in BAP1, ARIDIA and PBRM1 in intrahepatic cholangiocarcinomas. Nat Genet 45: 1470-1473.

Jones S, Wang TL, Shih Ie M, Mao TL, Nakayama K, Roden R, Glas R, Slamon D, Diaz LA Jr, Vogelstein B, et al. 2010. Frequent mutations of chromatin remodeling gene 
C. Hodges et al.

ARID1A in ovarian clear cell carcinoma. Science 330: $228-231$.

Kadoch C, Crabtree GR. 2013. Reversible disruption of mSWI/SNF (BAF) complexes by the SS18-SSX oncogenic fusion in synovial sarcoma. Cell 153: 71-85.

Kadoch C, Hargreaves DC, Hodges C, Elias L, Ho L, Ranish J, Crabtree GR. 2013. Proteomic and bioinformatic analysis of mammalian SWI/SNF complexes identifies extensive roles in human malignancy. Nat Genet 45: 592-601.

Kaeser MD, Aslanian A, Dong MQ, Yates JR III, Emerson BM. 2008. BRD7, a novel PBAF-specific SWI/SNF subunit, is required for target gene activation and repression in embryonic stem cells. J Biol Chem 283: 32254-32263.

Kagey MH, Newman JJ, Bilodeau S, Zhan Y, Orlando DA, van Berkum NL, Ebmeier CC, Goossens J, Rahl PB, Levine SS, et al. 2010. Mediator and cohesin connect gene expression and chromatin architecture. Nature 467: 430435.

Kakarougkas A, Ismail A, Chambers AL, Riballo E, Herbert AD, Kunzel J, Lobrich M, Jeggo PA, Downs JA. 2014. Requirement for PBAF in transcriptional repression and repair at DNA breaks in actively transcribed regions of chromatin. Mol Cell 55: 723-732.

Kal AJ, Mahmoudi T, Zak NB, Verrijzer CP. 2000. The Drosophila Brahma complex is an essential coactivator for the trithorax group protein zeste. Genes Dev 14: 1058-1071.

Kandoth C, Schultz N, Cherniack AD, Akbani R, Liu Y, Shen H, Robertson AG, Pashtan I, Shen R, Benz CC, et al. 2013. Integrated genomic characterization of endometrial carcinoma. Nature 497: 67-73.

Kennison JA, Tamkun JW. 1988. Dosage-dependent modifiers of polycomb and antennapedia mutations in Drosophila. Proc Natl Acad Sci 85: 8136-8140.

Khavari PA, Peterson CL, Tamkun JW, Mendel DB, Crabtree GR. 1993. BRG1 contains a conserved domain of the SWI2/SNF2 family necessary for normal mitotic growth and transcription. Nature 366: 170-174.

Kia SK, Gorski MM, Giannakopoulos S, Verrijzer CP. 2008. SWI/SNF mediates polycomb eviction and epigenetic reprogramming of the INK $4 b$-ARF-INK $4 a$ locus. $M o l$ Cell Biol 28: 3457-3464.

Kim KH, Kim W, Howard TP, Vazquez F, Tsherniak A, Wu JN, Wang W, Haswell JR, Walensky LD, Hahn WC, et al. 2015. SWI/SNF-mutant cancers depend on catalytic and non-catalytic activity of EZH2. Nat Med 21: 1491-1496.

Kingston RE, Tamkun JW. 2014. Transcriptional regulation by trithorax-group proteins. Cold Spring Harb Perspect Biol 6: a019349.

Kirkland JG, Raab JR, Kamakaka RT. 2013. TFIIIC bound DNA elements in nuclear organization and insulation. Biochim Biophys Acta 1829: 418-424.

Krasteva V, Buscarlet M, Diaz-Tellez A, Bernard MA, Crabtree GR, Lessard JA. 2012. The BAF53a subunit of SWI/ SNF-like BAF complexes is essential for hemopoietic stem cell function. Blood 120: 4720-4732.

Kruger W, Peterson CL, Sil A, Coburn C, Arents G, Moudrianakis EN, Herskowitz I. 1995. Amino acid substitutions in the structured domains of histones $\mathrm{H} 3$ and $\mathrm{H} 4$ partially relieve the requirement of the yeast SWI/SNF complex for transcription. Genes Dev 9: 2770-2779.
Laurent BC, Treich I, Carlson M. 1993. The yeast SNF2/ SWI2 protein has DNA-stimulated ATPase activity required for transcriptional activation. Genes Dev 7: $583-$ 591.

Lawrence MS, Stojanov P, Mermel CH, Robinson JT, Garraway LA, Golub TR, Meyerson M, Gabriel SB, Lander ES, Getz G. 2014. Discovery and saturation analysis of cancer genes across 21 tumour types. Nature 505: 495501.

Lee HS, Park JH, Kim SJ, Kwon SJ, Kwon J. 2010. A cooperative activation loop among SWI/SNF, $\gamma$-H2AX and H3 acetylation for DNA double-strand break repair. EMBO J 29: 1434-1445.

Lee RS, Stewart C, Carter SL, Ambrogio L, Cibulskis K, Sougnez C, Lawrence MS, Auclair D, Mora J, Golub TR, et al. 2012. A remarkably simple genome underlies highly malignant pediatric rhabdoid cancers. J Clin Invest 122: $2983-2988$.

Lee JJ, Sholl LM, Lindeman NI, Granter SR, Laga AC, Shivdasani P, Chin G, Luke JJ, Ott PA, Hodi FS, et al. 2015. Targeted next-generation sequencing reveals high frequency of mutations in epigenetic regulators across treatment-naive patient melanomas. Clin Epigenetics 7: 59.

Le Loarer F, Watson S, Pierron G, de Montpreville VT, Ballet S, Firmin N, Auguste A, Pissaloux D, Boyault S, Paindavoine $\mathrm{S}$, et al. 2015. SMARCA4 inactivation defines a group of undifferentiated thoracic malignancies transcriptionally related to BAF-deficient sarcomas. Nat $\mathrm{Ge}$ net 47: 1200-1205.

Lemon B, Inouye C, King DS, Tjian R. 2001. Selectivity of chromatin-remodelling cofactors for ligand-activated transcription. Nature 414: 924-928.

Leschziner AE, Lemon B, Tjian R, Nogales E. 2005. Structural studies of the human PBAF chromatin-remodeling complex. Structure 13: 267-275.

Leschziner AE, Saha A, Wittmeyer J, Zhang Y, Bustamante C, Cairns BR, Nogales E. 2007. Conformational flexibility in the chromatin remodeler RSC observed by electron microscopy and the orthogonal tilt reconstruction method. Proc Natl Acad Sci 104: 4913-4918.

Lessard J, Wu JI, Ranish JA, Wan M, Winslow MM, Staahl BT, Wu H, Aebersold R, Graef IA, Crabtree GR. 2007. An essential switch in subunit composition of a chromatin remodeling complex during neural development. Neuron 55: 201-215.

Li XS, Trojer P, Matsumura T, Treisman JE, Tanese N. 2010. Mammalian SWI/SNF-A subunit BAF250/ARID1 is an E3 ubiquitin ligase that targets histone H2B. Mol Cell Biol 30: 1673-1688.

Li M, Zhao H, Zhang X, Wood LD, Anders RA, Choti MA, Pawlik TM, Daniel HD, Kannangai R, Offerhaus GJ, et al. 2011. Inactivating mutations of the chromatin remodeling gene ARID2 in hepatocellular carcinoma. Nat Genet 43: $828-829$.

Li YY, Hanna GJ, Laga AC, Haddad RI, Lorch JH, Hammerman PS. 2015. Genomic analysis of metastatic cutaneous squamous cell carcinoma. Clin Cancer Res 21: 14471456.

Lickert H, Takeuchi JK, Von Both I, Walls JR, McAuliffe F, Adamson SL, Henkelman RM, Wrana JL, Rossant J, Bruneau BG. 2004. Baf60c is essential for function of BAF 
chromatin remodelling complexes in heart development. Nature 432: 107-112.

Lippman Z, Gendrel AV, Black M, Vaughn MW, Dedhia N, McCombie WR, Lavine K, Mittal V, May B, Kasschau KD, et al. 2004. Role of transposable elements in heterochromatin and epigenetic control. Nature 430: 471-476.

Liu R, Liu H, Chen X, Kirby M, Brown PO, Zhao K. 2001. Regulation of CSF1 promoter by the SWI/SNF-like BAF complex. Cell 106: 309-318.

Lunyak VV, Prefontaine GG, Nunez E, Cramer T, Ju BG, Ohgi KA, Hutt K, Roy R, Garcia-Diaz A, Zhu X, et al. 2007. Developmentally regulated activation of a SINE B2 repeat as a domain boundary in organogenesis. Science 317: $248-251$.

Manceau G, Letouze E, Guichard C, Didelot A, Cazes A, Corte H, Fabre E, Pallier K, Imbeaud S, Le PimpecBarthes F, et al. 2013. Recurrent inactivating mutations of ARID2 in non-small cell lung carcinoma. Int J Cancer 132: 2217-2221.

Manning BJ, Peterson CL. 2014. Direct interactions promote eviction of the Sir3 heterochromatin protein by the SWI/SNF chromatin remodeling enzyme. Proc Natl Acad Sci 111: 17827-17832.

McKenna ES, Roberts CW. 2009. Epigenetics and cancer without genomic instability. Cell Cycle 8: 23-26.

McKenna ES, Sansam CG, Cho YJ, Greulich H, Evans JA, Thom CS, Moreau LA, Biegel JA, Pomeroy SL, Roberts CW. 2008. Loss of the epigenetic tumor suppressor SNF5 leads to cancer without genomic instability. Mol Cell Biol 28: 6223-6233.

Medina PP, Sanchez-Cespedes M. 2008. Involvement of the chromatin-remodeling factor BRG1/SMARCA4 in human cancer. Epigenetics 3: 64-68.

Medina PP, Carretero J, Fraga MF, Esteller M, Sidransky D, Sanchez-Cespedes M. 2004. Genetic and epigenetic screening for gene alterations of the chromatin-remodeling factor, SMARCA4/BRG1, in lung tumors. Genes Chromosomes Cancer 41: 170-177.

Medina PP, Romero OA, Kohno T, Montuenga LM, Pio R, Yokota J, Sanchez-Cespedes M. 2008. Frequent BRG1/ SMARCA4-inactivating mutations in human lung cancer cell lines. Hum Mutat 29: 617-622.

Middeljans E, Wan X, Jansen PW, Sharma V, Stunnenberg HG, Logie C. 2012. SS18 together with animal-specific factors defines human BAF-type SWI/SNF complexes. PLoS ONE 7: e33834.

Mohrmann L, Langenberg K, Krijgsveld J, Kal AJ, Heck AJ, Verrijzer CP. 2004. Differential targeting of two distinct SWI/SNF-related Drosophila chromatin-remodeling complexes. Mol Cell Biol 24: 3077-3088.

Molnar C, Lopez-Varea A, Hernandez R, de Celis JF. 2006. A gain-of-function screen identifying genes required for vein formation in the Drosophila melanogaster wing. Genetics 174: 1635-1659.

Mora-Blanco EL, Mishina Y, Tillman EJ, Cho YJ, Thom CS, Pomeroy SL, Shao W, Roberts CW. 2014. Activation of $\beta$ catenin/TCF targets following loss of the tumor suppressor SNF5. Oncogene 33: 933-938.

Moshkin YM, Mohrmann L, van Ijcken WF, Verrijzer CP. 2007. Functional differentiation of SWI/SNF remodelers in transcription and cell cycle control. Mol Cell Biol 27: 651-661.

Naka N, Takenaka S, Araki N, Miwa T, Hashimoto N, Yoshioka K, Joyama S, Hamada K, Tsukamoto Y, Tomita Y, et al. 2010. Synovial sarcoma is a stem cell malignancy. Stem Cells 28: 1119-1131.

Narlikar GJ, Sundaramoorthy R, Owen-Hughes T. 2013. Mechanisms and functions of ATP-dependent chromatin-remodeling enzymes. Cell 154: 490-503.

Neigeborn L, Carlson M. 1984. Genes affecting the regulation of SUC2 gene expression by glucose repression in Saccharomyces cerevisiae. Genetics 108: 845-858.

Neigeborn L, Carlson M. 1987. Mutations causing constitutive invertase synthesis in yeast: Genetic interactions with snf mutations. Genetics 115: 247-253.

Niimi A, Chambers AL, Downs JA, Lehmann AR. 2012. A role for chromatin remodellers in replication of damaged DNA. Nucleic Acids Res 40: 7393-7403.

Niimi A, Hopkins SR, Downs JA, Masutani C. 2015. The BAH domain of BAF180 is required for PCNA ubiquitination. Mutat Res 779: 16-23.

Ogiwara H, Ui A, Otsuka A, Satoh H, Yokomi I, Nakajima S, Yasui A, Yokota J, Kohno T. 2011. Histone acetylation by CBP and p300 at double-strand break sites facilitates SWI/SNF chromatin remodeling and the recruitment of non-homologous end joining factors. Oncogene 30: 2135-2146.

Oki M, Valenzuela L, Chiba T, Ito T, Kamakaka RT. 2004. Barrier proteins remodel and modify chromatin to restrict silenced domains. Mol Cell Biol 24: 1956-1967.

Olave I, Wang W, Xue Y, Kuo A, Crabtree GR. 2002. Identification of a polymorphic, neuron-specific chromatin remodeling complex. Genes Dev 16: 2509-2517.

Oruetxebarria I, Venturini F, Kekarainen T, Houweling A, Zuijderduijn LM, Mohd-Sarip A, Vries RG, Hoeben RC, Verrijzer CP. 2004. P16 ${ }^{I N K 4 a}$ is required for hSNF5 chromatin remodeler-induced cellular senescence in malignant rhabdoid tumor cells. J Biol Chem 279: 3807-3816.

Pang B, de Jong J, Qiao X, Wessels LF, Neefjes J. 2015. Chemical profiling of the genome with anti-cancer drugs defines target specificities. Nat Chem Biol 11: 472-480.

Papoulas O, Beek SJ, Moseley SL, McCallum CM, Sarte M, Shearn A, Tamkun JW. 1998. The Drosophila trithorax group proteins BRM, ASH1 and ASH2 are subunits of distinct protein complexes. Development 125: 39553966.

Parnell TJ, Huff JT, Cairns BR. 2008. RSC regulates nucleosome positioning at Pol II genes and density at Pol III genes. EMBO J 27: 100-110.

Patrick KL, Ryan CJ, Xu J, Lipp JJ, Nissen KE, Roguev A, Shales M, Krogan NJ, Guthrie C. 2015. Genetic interaction mapping reveals a role for the SWI/SNF nucleosome remodeler in spliceosome activation in fission yeast. PLoS Genet 11: e1005074.

Peng G, Yim EK, Dai H, Jackson AP, Burgt I, Pan MR, Hu R, Li K, Lin SY. 2009. BRIT1/MCPH1 links chromatin remodelling to DNA damage response. Nat Cell Biol 11: 865-872.

Peterson CL, Herskowitz I. 1992. Characterization of the yeast SWI1, SWI2, and SWI3 genes, which encode a global activator of transcription. Cell 68: 573-583. 
C. Hodges et al.

Peterson CL, Dingwall A, Scott MP. 1994. Five SWI/SNF gene products are components of a large multisubunit complex required for transcriptional enhancement. Proc Natl Acad Sci 91: 2905-2908.

Peterson CL, Zhao Y, Chait BT. 1998. Subunits of the yeast SWI/SNF complex are members of the actin-related protein (ARP) family. J Biol Chem 273: 23641-23644.

Phelan ML, Sif S, Narlikar GJ, Kingston RE. 1999. Reconstitution of a core chromatin remodeling complex from SWI/SNF subunits. Mol Cell 3: 247-253.

Prensner JR, Iyer MK, Sahu A, Asangani IA, Cao Q, Patel L, Vergara IA, Davicioni E, Erho N, Ghadessi M, et al. 2013. The long noncoding RNA SChLAP1 promotes aggressive prostate cancer and antagonizes the SWI/SNF complex. Nat Genet 45: 1392-1398.

Pugh TJ, Weeraratne SD, Archer TC, Pomeranz Krumme DA, Auclair D, Bochicchio J, Carneiro MO, Carter SL, Cibulskis K, Erlich RL, et al. 2012. Medulloblastoma exome sequencing uncovers subtype-specific somatic mutations. Nature 488: 106-110.

Qi W, Wang R, Chen H, Wang X, Xiao T, Boldogh I, Ba X, Han L, Zeng X. 2015. BRG1 promotes the repair of DNA double-strand breaks by facilitating the replacement of RPA with RAD51. J Cell Sci 128: 317-330.

Raab JR, Resnick S, Magnuson T. 2015. Genome-wide transcriptional regulation mediated by biochemically distinct SWI/SNF complexes. PLoS Genet 11: e1005748.

Rada-Iglesias A, Bajpai R, Swigut T, Brugmann SA, Flynn RA, Wysocka J. 2011. A unique chromatin signature uncovers early developmental enhancers in humans. Nature 470: $279-283$.

Ramos P, Karnezis AN, Craig DW, Sekulic A, Russell ML, Hendricks WP, Corneveaux JJ, Barrett MT, Shumansky K, Yang Y, et al. 2014. Small cell carcinoma of the ovary, hypercalcemic type, displays frequent inactivating germline and somatic mutations in SMARCA4. Nat Genet 46: 427-429.

Rando OJ, Zhao K, Janmey P, Crabtree GR. 2002. Phosphatidylinositol-dependent actin filament binding by the SWI/SNF-like BAF chromatin remodeling complex. Proc Natl Acad Sci 99: 2824-2829.

Reinhold WC, Sunshine M, Liu H, Varma S, Kohn KW, Morris J, Doroshow J, Pommier Y. 2012. CellMiner: A web-based suite of genomic and pharmacologic tools to explore transcript and drug patterns in the NCI-60 cell line set. Cancer Res 72: 3499-3511.

Reisman DN, Strobeck MW, Betz BL, Sciariotta J, Funkhouser W Jr, Murchardt C, Yaniv M, Sherman LS, Knudsen ES, Weissman BE. 2002. Concomitant down-regulation of BRM and BRG1 in human tumor cell lines: Differential effects on RB-mediated growth arrest vs CD44 expression. Oncogene 21: 1196-1207.

Rendina R, Strangi A, Avallone B, Giordano E. 2010. Bap170, a subunit of the Drosophila PBAP chromatin remodeling complex, negatively regulates the EGFR signaling. Genetics 186: $167-181$.

Richmond E, Peterson CL. 1996. Functional analysis of the DNA-stimulated ATPase domain of yeast SWI2/SNF2. Nucleic Acids Res 24: 3685-3692.

Rizvi NA, Hellmann MD, Snyder A, Kvistborg P, Makarov V, Havel JJ, Lee W, Yuan J, Wong P, Ho TS, et al. 2015. Cancer immunology. Mutational landscape determines sensitiv- ity to PD-1 blockade in non-small cell lung cancer. Science 348: 124-128.

Roberts CW, Biegel JA. 2009. The role of SMARCB1/INI1 in development of rhabdoid tumor. Cancer Biol Ther 8: 412-416.

Roberts CW, Galusha SA, McMenamin ME, Fletcher CD, Orkin SH. 2000. Haploinsufficiency of Snf5 (integrase interactor 1) predisposes to malignant rhabdoid tumors in mice. Proc Natl Acad Sci 97: 13796-13800.

Santen GW, Aten E, Sun Y, Almomani R, Gilissen C, Nielsen M, Kant SG, Snoeck IN, Peeters EA, Hilhorst-Hofstee Y, et al. 2012. Mutations in SWI/SNF chromatin remodeling complex gene ARIDIB cause Coffin-Siris syndrome. Nat Genet 44: 379-380.

Sausen M, Leary RJ, Jones S, Wu J, Reynolds CP, Liu X, Blackford A, Parmigiani G, Diaz LA Jr, Papadopoulos $\mathrm{N}$, et al. 2013. Integrated genomic analyses identify ARID1A and ARIDIB alterations in the childhood cancer neuroblastoma. Nat Genet 45: 12-17.

Schnitzler GR, Cheung CL, Hafner JH, Saurin AJ, Kingston RE, Lieber CM. 2001. Direct imaging of human SWI/ SNF-remodeled mono- and polynucleosomes by atomic force microscopy employing carbon nanotube tips. Mol Cell Biol 21: 8504-8511.

Schoenfelder S, Sugar R, Dimond A, Javierre BM, Armstrong H, Mifsud B, Dimitrova E, Matheson L, TavaresCadete F, Furlan-Magaril M, et al. 2015. Polycomb repressive complex PRC1 spatially constrains the mouse embryonic stem cell genome. Nat Genet 47: 1179-1186.

Schubert HL, Wittmeyer J, Kasten MM, Hinata K, Rawling DC, Heroux A, Cairns BR, Hill CP. 2013. Structure of an actin-related subcomplex of the SWI/SNF chromatin remodeler. Proc Natl Acad Sci 110: 3345-3350.

Shain AH, Pollack JR. 2013. The spectrum of SWI/SNF mutations, ubiquitous in human cancers. PLOS ONE 8: e55119.

Shain AH, Garrido M, Botton T, Talevich E, Yeh I, Sanborn JZ, Chung J, Wang NJ, Kakavand H, Mann GJ, et al. 2015. Exome sequencing of desmoplastic melanoma identifies recurrent NFKBIE promoter mutations and diverse activating mutations in the MAPK pathway. Nat Genet 47: 1194-1199.

Shaver S, Casas-Mollano JA, Cerny RL, Cerutti H. 2010. Origin of the polycomb repressive complex 2 and gene silencing by an $\mathrm{E}(\mathrm{z})$ homolog in the unicellular alga Chlamydomonas. Epigenetics 5: 301-312.

Shen X, Ranallo R, Choi E, Wu C. 2003. Involvement of actin-related proteins in ATP-dependent chromatin remodeling. Mol Cell 12: 147-155.

Shi J, Wang E, Milazzo JP, Wang Z, Kinney JB, Vakoc CR. 2015. Discovery of cancer drug targets by CRISPR-Cas9 screening of protein domains. Nat Biotechnol 33: 661667.

Shim EY, Ma JL, Oum JH, Yanez Y, Lee SE. 2005. The yeast chromatin remodeler RSC complex facilitates end joining repair of DNA double-strand breaks. Mol Cell Biol 25: 3934-3944.

Simon JA, Tamkun JW. 2002. Programming off and on states in chromatin: Mechanisms of polycomb and trithorax group complexes. Curr Opin Genet Dev 12: 210-218. 
Singhal N, Graumann J, Wu G, Arauzo-Bravo MJ, Han DW, Greber B, Gentile L, Mann M, Scholer HR. 2010. Chromatin-remodeling components of the BAF complex facilitate reprogramming. Cell 141: 943-955.

Skene PJ, Hernandez AE, Groudine M, Henikoff S. 2014 The nucleosomal barrier to promoter escape by RNA polymerase II is overcome by the chromatin remodeler Chd1. eLife 3: $\mathrm{e} 02042$.

Smith CL, Peterson CL. 2005. A conserved Swi2/Snf2 ATPase motif couples ATP hydrolysis to chromatin remodeling. Mol Cell Biol 25: 5880-5892.

Smith CL, Horowitz-Scherer R, Flanagan JF, Woodcock CL, Peterson CL. 2003. Structural analysis of the yeast SWI/ SNF chromatin remodeling complex. Nat Struct Biol 10: 141-145.

Sperling AS, Jeong KS, Kitada T, Grunstein M. 2011. Topoisomerase II binds nucleosome-free DNA and acts redundantly with topoisomerase I to enhance recruitment of RNA Pol II in budding yeast. Proc Natl Acad Sci 108: 12693-12698.

Srivas R, Costelloe T, Carvunis AR, Sarkar S, Malta E, Sun SM, Pool M, Licon K, van Welsem T, van Leeuwen F, et al. 2013. A UV-induced genetic network links the RSC complex to nucleotide excision repair and shows dose-dependent rewiring. Cell Rep 5: 1714-1724.

Staahl BT, Tang J, Wu W, Sun A, Gitler AD, Yoo AS, Crabtree GR. 2013. Kinetic analysis of npBAF to nBAF switching reveals exchange of SS18 with CREST and integration with neural developmental pathways. J Neurosci 33: 10348-10361.

Stern M, Jensen R, Herskowitz I. 1984. Five SWI genes are required for expression of the $\mathrm{HO}$ gene in yeast. J Mol Biol 178: $853-868$

Sternberg PW, Stern MJ, Clark I, Herskowitz I. 1987. Activation of the yeast $H O$ gene by release from multiple negative controls. Cell 48: 567-577.

Szerlong H, Saha A, Cairns BR. 2003. The nuclear actinrelated proteins Arp7 and Arp9: A dimeric module that cooperates with architectural proteins for chromatin remodeling. EMBO J 22: 3175-3187.

Szerlong H, Hinata K, Viswanathan R, Erdjument-Bromage H, Tempst P, Cairns BR. 2008. The HSA domain binds nuclear actin-related proteins to regulate chromatin-remodeling ATPases. Nat Struct Mol Biol 15: 469-476.

Tamkun JW, Deuring R, Scott MP, Kissinger M, Pattatucci AM, Kaufman TC, Kennison JA. 1992. brahma: A regulator of Drosophila homeotic genes structurally related to the yeast transcriptional activator SNF2/SWI2. Cell 68: 561-572.

Taulli R, Foglizzo V, Morena D, Coda DM, Ala U, Bersani F, Maestro N, Ponzetto C. 2014. Failure to downregulate the BAF53a subunit of the SWI/SNF chromatin remodeling complex contributes to the differentiation block in rhabdomyosarcoma. Oncogene 33: 2354-2362.

Terriente-Felix A, de Celis JF. 2009. Osa, a subunit of the BAP chromatin-remodelling complex, participates in the regulation of gene expression in response to EGFR signalling in the Drosophila wing. Dev Biol 329: 350-361.

The Cancer Genome Atlas. 2012a. Comprehensive molecular characterization of human colon and rectal cancer. Nature 487: 330-337.
The Cancer Genome Atlas. 2012b. Comprehensive molecular portraits of human breast tumours. Nature 490: 6170.

The Cancer Genome Atlas. 2014a. Comprehensive molecular characterization of gastric adenocarcinoma. Nature 513: 202-209.

The Cancer Genome Atlas. 2014b. Comprehensive molecular characterization of urothelial bladder carcinoma. $\mathrm{Na}$ ture 507: 315-322.

The Cancer Genome Atlas. 2014c. Comprehensive molecular profiling of lung adenocarcinoma. Nature 511: $543-$ 550.

The Cancer Genome Atlas. 2015. Genomic classification of cutaneous melanoma. Cell 161: 1681-1696.

Thoma NH, Czyzewski BK, Alexeev AA, Mazin AV, Kowalczykowski SC, Pavletich NP. 2005. Structure of the SWI2/SNF2 chromatin-remodeling domain of eukaryotic Rad54. Nat Struct Mol Biol 12: 350-356.

Trouche D, Le Chalony C, Muchardt C, Yaniv M, Kouzarides T. 1997. RB and hbrm cooperate to repress the activation functions of E2F1. Proc Natl Acad Sci 94: 11268-11273.

Tsurusaki Y, Okamoto N, Ohashi H, Kosho T, Imai Y, HibiKo Y, Kaname T, Naritomi K, Kawame H, Wakui K, et al. 2012. Mutations affecting components of the SWI/SNF complex cause Coffin-Siris syndrome. Nat Genet 44: 376-378.

Tyagi A, Ryme J, Brodin D, Ostlund Farrants AK, Visa N. 2009. SWI/SNF associates with nascent pre-mRNPs and regulates alternative pre-mRNA processing. PLoS Genet 5: e1000470.

Varela I, Tarpey P, Raine K, Huang D, Ong CK, Stephens P, Davies H, Jones D, Lin ML, Teague J, et al. 2011. Exome sequencing identifies frequent mutation of the SWI/SNF complex gene PBRM1 in renal carcinoma. Nature 469: 539-542.

Versteege I, Sevenet N, Lange J, Rousseau-Merck MF, Ambros P, Handgretinger R, Aurias A, Delattre O. 1998. Truncating mutations of hSNF5/INI1 in aggressive paediatric cancer. Nature 394: 203-206.

Vogel-Ciernia A, Matheos DP, Barrett RM, Kramar EA, Azzawi S, Chen Y, Magnan CN, Zeller M, Sylvain A, Haettig J, et al. 2013. The neuron-specific chromatin regulatory subunit BAF53b is necessary for synaptic plasticity and memory. Nat Neurosci 16: 552-561.

Waldholm J, Wang Z, Brodin D, Tyagi A, Yu S, Theopold U, Farrants AK, Visa N. 2011. SWI/SNF regulates the alternative processing of a specific subset of pre-mRNAs in Drosophila melanogaster. BMC Mol Biol 12: 46.

Walker JE, Saraste M, Runswick MJ, Gay NJ. 1982. Distantly related sequences in the $\alpha$ - and $\beta$-subunits of ATP synthase, myosin, kinases and other ATP-requiring enzymes and a common nucleotide binding fold. EMBO J 1: 945951.

Wang W, Cote J, Xue Y, Zhou S, Khavari PA, Biggar SR, Muchardt C, Kalpana GV, Goff SP, Yaniv M, et al. 1996a. Purification and biochemical heterogeneity of the mammalian SWI-SNF complex. EMBO J 15: 5370 5382 .

Wang W, Xue Y, Zhou S, Kuo A, Cairns BR, Crabtree GR. 1996b. Diversity and specialization of mammalian SWI/ SNF complexes. Genes Dev 10: 2117-2130. 
C. Hodges et al.

Wang W, Chi T, Xue Y, Zhou S, Kuo A, Crabtree GR. 1998 Architectural DNA binding by a high-mobility-group/ kinesin-like subunit in mammalian SWI/SNF-related complexes. Proc Natl Acad Sci 95: 492-498.

Wang K, Kan J, Yuen ST, Shi ST, Chu KM, Law S, Chan TL, Kan Z, Chan AS, Tsui WY, et al. 2011a. Exome sequencing identifies frequent mutation of ARIDIA in molecular subtypes of gastric cancer. Nat Genet 43: 1219-1223.

Wang X, Werneck MB, Wilson BG, Kim HJ, Kluk MJ, Thom CS, Wischhusen JW, Evans JA, Jesneck JL, Nguyen P, et al. 2011b. TCR-dependent transformation of mature memory phenotype T cells in mice. J Clin Invest 121: 3834-3845.

Wang H, Maurano MT, Qu H, Varley KE, Gertz J, Pauli F, Lee K, Canfield T, Weaver M, Sandstrom R, et al. 2012. Widespread plasticity in CTCF occupancy linked to DNA methylation. Genome Res 22: 1680-1688.

Wang K, Yuen ST, Xu J, Lee SP, Yan HH, Shi ST, Siu HC, Deng S, Chu KM, Law S, et al. 2014. Whole-genome sequencing and comprehensive molecular profiling identify new driver mutations in gastric cancer. Nat Genet 46: $573-582$.

Wani AH, Boettiger AN, Schorderet P, Ergun A, Munger C, Sadreyev RI, Zhuang X, Kingston RE, Francis NJ. 2016. Chromatin topology is coupled to Polycomb group protein subnuclear organization. Nat Commun 7: 10291.

Watanabe R, Ui A, Kanno S, Ogiwara H, Nagase T, Kohno T, Yasui A. 2014. SWI/SNF factors required for cellular resistance to DNA damage include ARID1A and ARID1B and show interdependent protein stability. Cancer Res 74: 2465-2475.

Wiegand KC, Shah SP, Al-Agha OM, Zhao Y, Tse K, Zeng T, Senz J, McConechy MK, Anglesio MS, Kalloger SE, et al. 2010. ARIDIA mutations in endometriosis-associated ovarian carcinomas. $N$ Engl J Med 363: 1532-1543.

Wijdeven RH, Pang B, van der Zanden SY, Qiao X, Blomen V, Hoogstraat M, Lips EH, Janssen L, Wessels L, Brummelkamp TR, et al. 2015. Genome-wide identification and characterization of novel factors conferring resistance to topoisomerase II poisons in cancer. Cancer Res 75: 4176-4187.

Wilson BG, Wang X, Shen X, McKenna ES, Lemieux ME, Cho YJ, Koellhoffer EC, Pomeroy SL, Orkin SH, Roberts CW. 2010. Epigenetic antagonism between polycomb and SWI/SNF complexes during oncogenic transformation. Cancer Cell 18: 316-328.

Wilson BG, Helming KC, Wang X, Kim Y, Vazquez F, Jagani Z, Hahn WC, Roberts CW. 2014. Residual complexes containing SMARCA2 (BRM) underlie the oncogenic drive of SMARCA4 (BRG1) mutation. Mol Cell Biol 34: 1136-1144.
Winston F, Carlson M. 1992. Yeast SNF/SWI transcriptional activators and the SPT/SIN chromatin connection. Trends Genet 8: 387-391.

Wollmann P, Cui S, Viswanathan R, Berninghausen O, Wells MN, Moldt M, Witte G, Butryn A, Wendler P, Beckmann R, et al. 2011. Structure and mechanism of the Swi2/Snf2 remodeller Mot1 in complex with its substrate TBP. $\mathrm{Na}$ ture 475: 403-407.

Wong AK, Shanahan F, Chen Y, Lian L, Ha P, Hendricks K, Ghaffari S, Iliev D, Penn B, Woodland AM, et al. 2000. $B R G 1$, a component of the SWI-SNF complex, is mutated in multiple human tumor cell lines. Cancer Res 60: 61716177.

Wu JI, Lessard J, Olave IA, Qiu Z, Ghosh A, Graef IA, Crabtree GR. 2007. Regulation of dendritic development by neuron-specific chromatin remodeling complexes. Neuron 56: $94-108$.

Xia L, Jaafar L, Cashikar A, Flores-Rozas H. 2007. Identification of genes required for protection from doxorubicin by a genome-wide screen in Saccharomyces cerevisiae. Cancer Res 67: 11411-11418.

Xu F, Flowers S, Moran E. 2012. Essential role of ARID2 protein-containing SWI/SNF complex in tissue-specific gene expression. J Biol Chem 287: 5033-5041.

Xue Y, Canman JC, Lee CS, Nie Z, Yang D, Moreno GT, Young MK, Salmon ED, Wang W. 2000. The human SWI/SNF-B chromatin-remodeling complex is related to yeast rsc and localizes at kinetochores of mitotic chromosomes. Proc Natl Acad Sci 97: 13015-13020.

Yan J, Enge M, Whitington T, Dave K, Liu J, Sur I, Schmierer B, Jolma A, Kivioja T, Taipale M, et al. 2013. Transcription factor binding in human cells occurs in dense clusters formed around cohesin anchor sites. Cell 154: 801-813.

Yoo AS, Staahl BT, Chen L, Crabtree GR. 2009. MicroRNAmediated switching of chromatin-remodelling complexes in neural development. Nature 460: 642-646.

Yoo AS, Sun AX, Li L, Shcheglovitov A, Portmann T, Li Y, Lee-Messer C, Dolmetsch RE, Tsien RW, Crabtree GR. 2011. MicroRNA-mediated conversion of human fibroblasts to neurons. Nature 476: 228-231.

Zhang X, Sun Q, Shan M, Niu M, Liu T, Xia B, Liang X, Wei W, Sun S, Zhang Y, et al. 2013. Promoter hypermethylation of ARID1A gene is responsible for its low mRNA expression in many invasive breast cancers. PLOS ONE 8: e53931.

Zhao K, Wang W, Rando OJ, Xue Y, Swiderek K, Kuo A, Crabtree GR. 1998. Rapid and phosphoinositol-dependent binding of the SWI/SNF-like BAF complex to chromatin after $\mathrm{T}$ lymphocyte receptor signaling. Cell $\mathbf{9 5}$ $625-636$. 


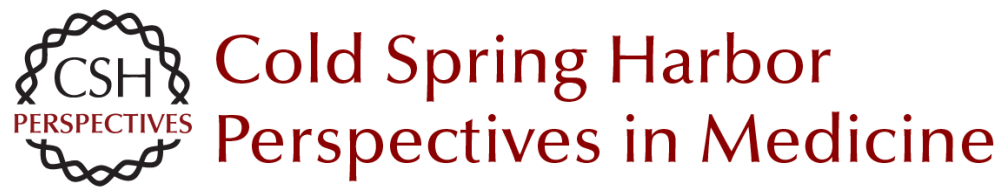

\section{The Many Roles of BAF (mSWI/SNF) and PBAF Complexes in Cancer}

Courtney Hodges, Jacob G. Kirkland and Gerald R. Crabtree

Cold Spring Harb Perspect Med 2016; doi: 10.1101/cshperspect.a026930 originally published online July 13, 2016

\section{Subject Collection Chromatin Deregulation in Cancer}

\section{Mixed-Lineage Leukemia Fusions and Chromatin in Leukemia \\ Andrei V. Krivtsov, Takayuki Hoshii and Scott A. Armstrong}

Targeting Cancer Cells with BET Bromodomain Inhibitors

$$
\text { Yali Xu and Christopher R. Vakoc }
$$

The Role of Nuclear Receptor-Binding SET Domain Family Histone Lysine Methyltransferases in Cancer

Richard L. Bennett, Alok Swaroop, Catalina Troche, et al.

SETting the Stage for Cancer Development:

SETD2 and the Consequences of Lost Methylation Catherine C. Fahey and lan J. Davis

ATRX and DAXX: Mechanisms and Mutations Michael A. Dyer, Zulekha A. Qadeer, David Valle-Garcia, et al.

DNMT3A in Leukemia

Lorenzo Brunetti, Michael C. Gundry and Margaret A. Goodell

Oncogenic Mechanisms of Histone H3 Mutations Daniel N. Weinberg, C. David Allis and Chao Lu

Nonhistone Lysine Methylation in the Regulation of Cancer Pathways

Scott M. Carlson and Or Gozani
TET2 in Normal and Malignant Hematopoiesis Robert L. Bowman and Ross L. Levine

Long Noncoding RNAs: At the Intersection of Cancer and Chromatin Biology Adam M. Schmitt and Howard Y. Chang

DNA Hypomethylating Drugs in Cancer Therapy Takahiro Sato, Jean-Pierre J. Issa and Patricia Kropf

The Chromodomain Helicase DNA-Binding Chromatin Remodelers: Family Traits that Protect from and Promote Cancer Alea A. Mills

Exploitation of EP300 and CREBBP Lysine Acetyltransferases by Cancer Narsis Attar and Siavash K. Kurdistani

Histone Lysine Demethylase Inhibitors Ashwini Jambhekar, Jamie N. Anastas and Yang Shi

Cohesin Mutations in Cancer Magali De Koninck and Ana Losada

MLL3/MLL4/COMPASS Family on Epigenetic Regulation of Enhancer Function and Cancer Christie C. Sze and Ali Shilatifard

For additional articles in this collection, see http://perspectivesinmedicine.cshlp.org/cgi/collection/ 